\title{
A REVIEW OF THE IGUANID LIZARD GENUS ENYALIUS
}

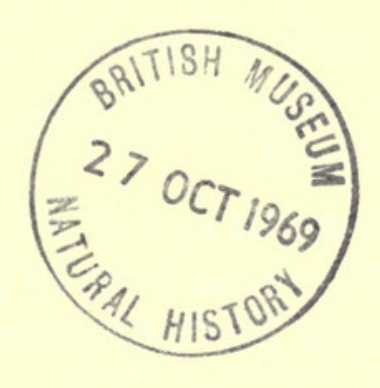

BY

RICHARD ETHERIDGE

Pp. 23I-260 ; II Text-figures

\begin{abstract}
BULLETIN OF
THE BRITISH MUSEUM (NATURAL HISTORY) ZOOLOGY Vol. I 8 No. 8

LONDON : 1969
\end{abstract}


The Bulletin OF The BRitish MUSEum (NATURAL HISTORY), instituted in I949, is issued in five series corresponding to the Departments of the Museum, and an Historical series.

Parts will appear at irregular intervals as they become ready. Volumes will contain about three or four hundred pages, and will not necessarily be completed within one calendar year.

In I965 a separate supplementary series of longer papers was instituted, numbered serially for each Department.

This paper is Vol. I8, No. 8 of the Zoological series. The abbreviated titles of periodicals cited follow those of the World List of Scientific Periodicals.

World List abbreviation

Bull. Br. Mus. nat. Hist. (Zool.).

(C) Trustees of the British Museum (Natural History), I969 


\title{
A REVIEW OF THE IGUANID LIZARD GENUS ENYALIUS
}

\author{
By RICHARD ETHERIDGE
}

\section{SYNOPSIS}

The external morphology, distribution, and systematics of the iguanid lizard genus Enyalius are reviewed. Eight species are recognized, one of them described here as new. Enyalius is compared with Enyalioides, Anisolepis, and Aptycholaemus, and a key is given to the species of Enyalius.

\section{INTRODUCTION}

Enyalius is a genus of arboreal iguanid lizards that inhabits forested areas in eastern South America. It has remained rare in the collections of North American museums, but during a recent tour of European museums I was able to examine excellent series of most of the species that have been described. Although many of these collections were made during the latter part of the last and the early part of the present century no attempt has been made to review the genus since Boulenger's (I885b) Catalogue of the Lizards in the British Museum. On the basis of these collections, and the few specimens available in North America, I have undertaken a review of the genus. Its purpose is to define and characterize the genus Enyalius, compare it with those genera to which it appears to be allied, and present characterizations and synonomies of the species. Unfortunately most of the specimens examined have only very general or imprecise locality data so that the exact geographical distribution of the species cannot be determined. Little has been published on the colour of living animals, or on their habits. Therefore a generic revision in the "modern" sense cannot yet be attempted.

The first species now known under the generic name Enyalius was described by Wied (I82I : 247) as Agama catenata. Three species described by Spix (I825:9-II) as Lophyrus rhombifer, L. margaritaceus, and L. albomaxillaris all appear to be referable to Wied's Agama catenata.

A second form described by Wied (I825: I25) as Agama picta has been placed in the genera Ecphymotes (Fitzinger, I826 : 49), Uraniscodon (Kaup, I826 : 9I ; I827 : 6I2 ; Gray, I845 : 223), Hypsibatus (Wagler, I830 : I50 ; Wiegmann, I834 : I5 ; Fitzinger, I843:58), Ophyessa (Gray, I83I : 40), Calotes (Schinz, I835:86), and Uperanodon (Duméril \& Bibron, I837 : 25I). Boulenger (I885b : I79) placed this form in the synonomy of Uraniscodon (= Plica) umbra, and this allocation has been followed by all subsequent authors. Wied's Agama picta is nevertheless a valid 
species of Enyalius. The same species was described as Enyalius zonatus by Wettstein (I926: I).

Lesson (I828:32) described Lophyrus brasiliensis, a valid species of Enyalius that has been considered by Boulenger (I885b : II 8 ) and all subsequent authors to be a synonym of Enyalius catenatus.

In I830 Wagler proposed the generic name Enyalius for Agama catenata and Lophyrus margaritaceus. Up to this time the generic names that had been applied to species of this genus were Agama (Wied, I82I : 247 ; I825 : I25), Lophyrus (Spix, I825:9-II ; Lesson, I828:32), Ecphymotes (Fitzinger, I826:49), and Uraniscodon (Kaup, I826 : 90-9I). All of these generic names are unavailable for Agama catenata. Fitzinger (I843 : I6) designated Agama catenata Wied as the type species of Hypsibatus (Enyalius).

Duméril \& Bibron (I837 : 234) described Enyalius bilineatus, a species that has until now been known under the name Enyalius fitzingeri. The error dates from Boulenger (I885b : I2I) who adopted Wiegmann's (I834:47) name Laemanctus fitzinger for the species, a name which Wiegmann based upon a specimen of Anisolepis undulatus. Duméril \& Bibron (I837:23I) also referred several specimens to Enyalius rhombifer, one of which is a specimen of Enyalius brasiliensis, and the other two of which represent an as yet unnamed species described later in this paper.

Boulenger described two additional species of Enyalius : iheringii (I885a : I92), and bibronii (I885b:II9). Boulenger (I885b:II2) also described the genus Enyalioides for a number of species that had until that time been included in Enyalius. All of the previously described species that he transferred to Enyalioides properly belong there, but his new species, Enyalioides leechii described in the same work (1885b : 473) is actually a species of Enyalins.

\section{ACKNOWLEDGEMENTS}

During the course of this study I have worked in a number of museums in Europe and in the United States. I should like to express my appreciation to those curators who have allowed me to examine the collections in their care : Dr. C. M. Bogert, American Museum of Natural History, New York ; Dr. F. W. Braestrup, Zoologiske Museum, København ; Dr. J. Eiselt, Naturhistorischen Museum, Wien ; Miss A. G. C. Grandison, British Museum (Natural History), London; Dr. W. Hellmich, Zoologisches Sammlung des Bayerischen Staates, München ; Dr. R. F. Inger, Field Museum of Natural History, Chicago; Dr. K. Klemmer, Natur-Museum und Forschungs-Institut Senckenberg, Frankfurt am Main ; Dr. W. Ladiges, Zoologisches Staatsinstitut und Zoologisches Museum, Hamburg; Dr. A. Leviton, California Academy of Sciences, San Francisco ; Dr. U. Parenti, Istituto e Museo de Zoologia della Universita di Torino; Dr. G. Peters, Zoologisches Museum der Humboldt Universität, Berlin; Dr. J. A. Peters, United States National Museum; Dr. R. Stebbins, Museum of Vertebrate Zoology, University of California, Berkeley ; Dr. E. E. Williams, Museum of Comparative Zoology, Harvard University, Cambridge (Massachusetts).

I am especially grateful to Miss A. G. C. Grandison and her staff at the British 
Museum (Natural History) where most of this work, including the initial stages in the preparation of this manuscript, was undertaken.

Financial support for this study was received, in part, from a grant by the Program for Systematic Biology of the National Science Foundation (Grant No. B5-2409).

The following abbreviations are used :

A.M.N.H. American Museum of Natural History, New York.

B.M.N.H. British Museum (Natural History), London.

C.A.S. California Academy of Sciences, San Francisco.

F.M.N.H. Field Museum of Natural History, Chicago.

M.C.Z. Museum of Comparative Zoology, Harvard University, Cambridge (Massachusetts).

M.H.N.P. Muséum National d'Histoire Naturelle, Paris.

M.V.Z. Museum of Vertebrate Zoology, University of California, Berkeley.

M.Z.T. Istituto e Museo de Zoologia della Universita di Torino, Torino.

N.M.W. Naturhistorischen Museum, Wien.

S.M.F. Natur-Museum und Forschungs-Institut Senckenberg, Frankfurt am Main.

U.S.N.M. United States National Museum, Washington.

Z.M.H. Zoologisches Staatsinstitut und Zoologisches Museum, Hamburg.

Z.M.K. Zoologiske Museum, København.

Z.S.B.S. Zoologisches Sammlung des Bayerischen Staates, München.

ENYALIUS Wagler, I830, Nat. Syst. Amph., p. I50.

TyPe SPEcies Agama catenata Wied., by designation (Fitzinger, I843 : I6).

Diagnosis. Enyalius is a member of that group of iguanid lizards in which the anterior inscriptional ribs extend from the distal ends of the dorsal ribs to the ventral midline, where they join one another to form continuous chevrons, and the posterior inscriptional ribs either form chevrons that are unattached to the dorsal ribs, or are absent (Etheridge, I965: I63-I66). Within this group Enyalius differs from the anoles (Anolis, Chamaeleolis, Chamaelinorops, Phenacosaurus, Tropidodactylus) in lacking both transversely expanded subdigital lamellae and an extensile gular fan ; a few anoles lack one or the other of these features, but never both. Enyalius differs from Enyalioides, Hoplocercus, and Morunasaurus in having a small nasal scale with a laterally oriented nostril ; the nasal scale is very large and the nostril is posterolaterally oriented in the latter three genera (Fig. II). Enyalius differs from Leiosaurus, Diplolaemus, Aperopristis, Pristidactylus, and Cupriguanus in having a compressed body, longer digits and longer limbs, and a longer tail. Enyalius differs from Polychrus in lacking femoral pores, and from Urostrophus, Anisolepis, and Aptycholaemus in having a row of enlarged scales aligned middorsally.

Characteristics. Upper head scales polygonal and juxtaposed, smooth and flat or convex, or convex and keeled. Supraorbital semicircles each with 9 to I5 scales somewhat larger and more strongly convex than those adjacent, medially separated 
between the orbits by two or three scales. Supraoculars small laterally, enlarged medially and centrally, the largest equal to, to much smaller than scales of supraorbital semicircles. Interparietal scale small, a little larger than parietals, with a distinct " eye ". Nasal scales small, strongly convex, below the canthal ridge, with a large, laterally oriented nostril. Canthal ridge distinct, with one or two large, overlapping scales. Seven to I4 superciliaries, the first few elongate with oblique sutures, the remainder squarish with vertical sutures. Loreal scales polygonal and juxtaposed, smooth or keeled. Orbit bordered in front and below by an arc of large scales, keeled along their upper border or with a median keel, subequal or one of them conspicuously elongate below the eye. Upper labials more or less rectangular, separated from loreals by several irregular rows of very small scales, and from suboculars by one or two rows of scales. Temporals usually polygonal and juxtaposed, smooth and flat or convex, or obtusely keeled, those overlying supratemporal arcade somewhat enlarged. Lower labials similar to upper labials. Lateral gulars polygonal and juxtaposed, smooth and convex, grading medially into smaller, rounded, convex, smooth or keeled scales with granules in the interspaces, and posteriorly becoming abruptly larger and imbricate in front of gular fold.

A middorsally aligned row of vertebral scales present, enlarged and forming a serration or crest down the middle of the back in all species save one. Dorsal and lateral nuchal scales small, convex, and granular. Dorsal scales of body adjacent to vertebral row polygonal, juxtaposed, of various sizes, smooth or obtusely keeled, laterally grading into smaller, rounded, convex scales with more or less triangular granules in between. Ventral scales of body several times larger than dorsals, arranged more or less in transverse rows, smooth or keeled.

Tail long and slender, from about one and a half to nearly three times longer than the head and body together, slightly compressed at its base, rounded for most of its length. Caudal vertebrae autotomic or not, when autotomic caudal scales arranged in segments that correspond to autotomic segments of vertebral column, with five to seven dorsal and three ventral scale rows in each segment (Fig. IOc) ; when caudal vertebrae are not autotomic caudal scales arranged irregularly with no trace of segmentation (Fig. IOA).

Dorsal scales of forelimb and of antibrachium rhomboidal, somewhat larger than body scales, subimbricate to imbricate, smooth or obtusely keeled. Ventral scales of brachium small, convex, and juxtaposed. Posterior surface of thigh covered with small, convex, juxtaposed scales that continue up onto the dorsal surface of the thigh to about midway along the femoral axis. Remainder of hind limb covered with large, rhomboidal, subimbricate to imbricate, smooth or obtusely keeled scales. Subdigital lamellae smooth and convex, or slightly or distinctly keeled ; if smooth a median longitudinal groove divides distal four or five lamellae of each digit.

A distinct transverse gular fold enclosing granular scales present, ascending on each side of neck in front of forelimb, and curving back over forelimb insertion, fading out on shoulder or at some point further back along side of body. No femoral or preanal pores.

Pattern highly variable, but basically brownish (in preservative) above, with a pair of light paravertebral stripes and alternating light and dark crossbands. Pattern 
variously modified by loss of paravertebral stripes or crossbands, constriction or interruption of crossbands by stripes, alternation of crossbands, etc. Males without a pattern, or pattern of reduced intensity in some species.

\section{Enyalius bilineatus Duméril \& Bibron}

Enyalius bilineatus Duméril \& Bibron, 1837, p. 234.

Hypsibatus (Dryophilus) bilineatus Fitzinger, 1843, p. 57.

Enyalius fitzingeri Boulenger, 1885b, p. I2I.

Holotype. M.H.N.P. No. 68I7, from "Brésil ".

Characteristics. (Fig. I). The dorsal head scales are smooth and flat. Several rows of enlarged supraoculars are partly or completely separated from the

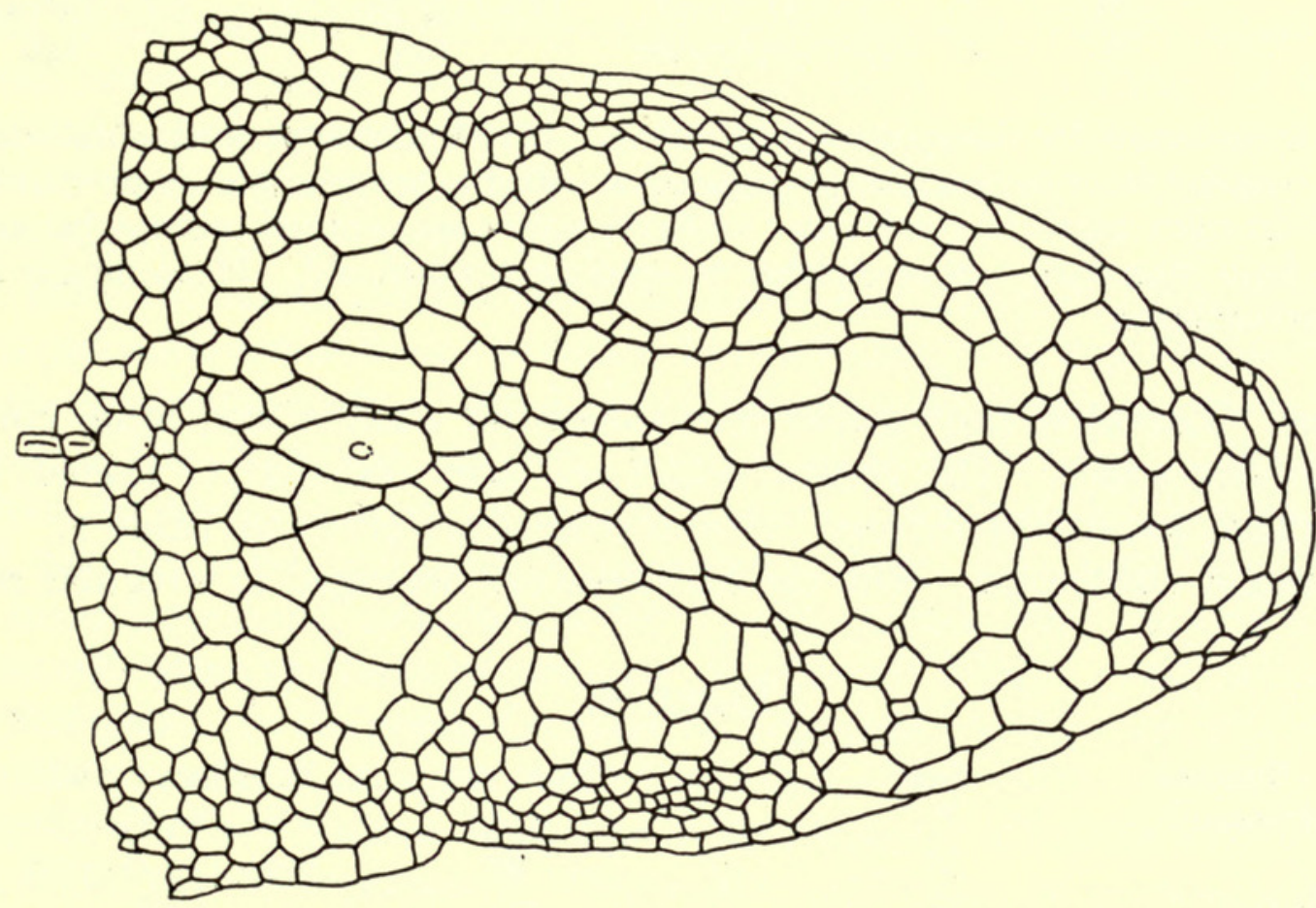

FIG. I. Dorsal view of the head of Enyalius bilineatus (Z.M.K. No. 5).

supraorbital semicircles by a row of small circumorbitals, and grade laterally into several rows of much smaller scales. The largest supraoculars are about equal in size to the scales of the supraorbital semicircles. The distance between the nasal scale and the tip of the snout is about one-half the distance between the nasal and anterior corner of the orbit. The orbit is usually bordered below by an elongate scale, preceded by two shorter, but otherwise similar scales, all of which have a keel along their upper margins. Occasionally the orbit is bordered in front and below by an arc of four subequal scales. The temporals are polygonal, juxtaposed, and keeled.

A vertebral row of enlarged, keeled scales extends from the occiput to the base of the tail, forming a low serration down the middle of the back. The dorsal scales adjacent to the vertebral row are polygonal, subimbricate, distinctly keeled, and of 


\section{TABLE I}

\begin{tabular}{|c|c|c|c|c|c|}
\hline Snecioc & Sex & & Vertebral & $\begin{array}{c}\text { Paravertebral } \\
\text { Scales }\end{array}$ & $\begin{array}{l}\text { Midbody } \\
\text { Scales }\end{array}$ \\
\hline \multirow[t]{2}{*}{ bilineatus } & F & $\begin{array}{l}\text { N } \\
\text { I9 }\end{array}$ & 46-(59:3)-74 & $94-\left(I_{4} \cdot 4\right)-130$ & $81-(93 \cdot 8)-106$ \\
\hline & M & 8 & $53-(62 \cdot I)-71$ & $98-(116 \cdot 4)-132$ & $85-(96 \cdot 6)-104$ \\
\hline \multirow[t]{2}{*}{ pictus } & $\mathrm{F}$ & 2 & $47-(47 \cdot 5)-48$ & I53-(I 59.5)-I66 & $\mathrm{I}_{4} 6-(\mathrm{I} 47 \cdot 0)-\mathrm{I}_{4}^{8}$ \\
\hline & M & 3 & $43-(50 \cdot 0)-59$ & I $53-\left(1_{55.5}\right)-I_{57}$ & I $54-($ I6o.o) - I 66 \\
\hline bibronii & $\mathrm{F}$ & 2 & $6 I-(63.5)-66$ & I $35-\left(I_{47} \cdot 0\right)-159$ & $102-(125 \cdot 0)-149$ \\
\hline \multirow[t]{2}{*}{ catenatus } & $\mathrm{F}$ & I4 & $40-(48 \cdot 6)-6 I$ & $125-(145 \cdot 2)-163$ & $130-(143 \cdot 0)-164$ \\
\hline & M & 9 & $45-(50 \cdot I)-5^{8}$ & $130-(146 \cdot 3)-164$ & $132-\left(I_{42} \cdot 0\right)-165$ \\
\hline \multirow[t]{2}{*}{ iheringii } & $\mathrm{F}$ & 72 & $40-(47 \cdot 9)-6 \mathrm{I}$ & $100-\left(\begin{array}{ll}1 & 5 \cdot 7)-131\end{array}\right.$ & $102-\left(I_{7} \cdot 4\right)-136$ \\
\hline & M & 35 & $40-(46 \cdot 6)-5^{8}$ & $9 \mathrm{I}-(\mathrm{I} 10 \cdot 8)-130$ & $103-(117 \cdot 6)-130$ \\
\hline \multirow[t]{2}{*}{ brasiliensis } & $\mathrm{F}$ & 3 & $45-(46 \cdot 3)-48$ & I30-(I38.3)-I49 & $152-\left(I_{5} 6 \cdot 0\right)-162$ \\
\hline & M & 5 & $47-(49 \cdot 2)-5 I$ & $146-(149 \cdot 2)-154$ & $I_{4} 6-\left(I_{5} I \cdot 5\right)-I 60$ \\
\hline \multirow[t]{2}{*}{ boulengeri } & $\mathrm{F}$ & 20 & $33-\left(3^{8 \cdot 5}\right)-43$ & $123-(138 \cdot 7)-162$ & IIO-(I27.4)-145 \\
\hline & M & 7 & $34-(37 \cdot 6)-4 I$ & I27-(I38.8)-I 57 & II6-(I28.4)-142 \\
\hline leechii & $\mathrm{F}$ & I & Not applicable & I43 & \\
\hline
\end{tabular}

Some scale counts for the species of Enyalius. Vertebral and paravertebral scales are counted from the occiput to a line even with the anterior border of the hind limb at right angles to the trunk ; midbody scales are counted halfway between the limb insertions. $\mathrm{N}=$ number of specimens examined. Mean figures are in parentheses.

various sizes. Laterally they grade into somewhat smaller and more convex but otherwise similar scales. The ventral scales are large and sharply keeled, the keels forming parallel, longitudinal rows. Scales counts are given in Table $\mathbf{r}$.

The tail is not autotomic. The caudal scales are arranged in irregular rows with

\section{TABLE II}

\begin{tabular}{|c|c|c|c|c|}
\hline Species & Sex & $\mathrm{N}$ & Max. s-v & Tail/Snout-vent \\
\hline \multirow[t]{2}{*}{ bilineatus } & $\mathrm{F}$ & Io & I05 & $2 \cdot 62-(2 \cdot 92)-3 \cdot 3 I$ \\
\hline & M & 9 & 88 & $2 \cdot 92-(3 \cdot 12)-3 \cdot 30$ \\
\hline \multirow[t]{2}{*}{ pictus } & $\mathrm{F}$ & I & III & $\mathrm{I} \cdot 96$ \\
\hline & M & 3 & Io6 & $2 \cdot 09-(2 \cdot 12)-2 \cdot 17$ \\
\hline bibronii & $\mathrm{F}$ & I & I00 & $\mathrm{I} \cdot 86$ \\
\hline \multirow[t]{2}{*}{ catenatus } & $\mathrm{F}$ & II & 107 & $I \cdot 98-(2 \cdot 20)-2 \cdot 34$ \\
\hline & M & Io & I07 & $2 \cdot 13-(2 \cdot 20)-2 \cdot 36$ \\
\hline \multirow[t]{2}{*}{ iheringii } & $\mathrm{F}$ & 54 & 124 & $I \cdot 94-(2 \cdot 08)-2 \cdot 37$ \\
\hline & M & 25 & 100 & $2 \cdot O I-\left(2 \cdot I_{5}\right)-2 \cdot 25$ \\
\hline \multirow[t]{2}{*}{ brasiliensis } & $\mathrm{F}$ & 2 & I05 & $2 \cdot 04-(2 \cdot 06)-2 \cdot 08$ \\
\hline & M & 3 & 85 & $2 \cdot 05-(2 \cdot 19)-2 \cdot 50$ \\
\hline \multirow[t]{2}{*}{ boulengeri } & $\mathrm{F}$ & 22 & II 7 & $I \cdot 59-(I \cdot 7 I)-I \cdot 92$ \\
\hline & M & 7 & I07 & $I \cdot 72-(I \cdot 79)-I \cdot 86$ \\
\hline leechii & $\mathrm{F}$ & I & 105 & $\mathrm{I} \cdot 75$ \\
\hline
\end{tabular}

Maximum size in millimetres snout-vent length (Max. s-v), and variation in the ratios of tail length divided by snout-vent length (Tail/ Snout-vent) in the species of Enyalius. $\mathrm{N}=$ number of specimens used in calculation of tail/snout-vent ratios. Note : Males of bibronii and leechii are unknown. 
no trace of segmentation (Fig. 9A). Variation in snout-vent length to tail length ratios, and maximum adult sizes of both sexes are given in Table 2 .

The subdigital lamellae are smooth and convex, the distal four or five lamellae of each digit medially divided. The fourth toe of the adpressed hind limb reaches a point between the orbit and the tip of the snout.

Colour in preservative: The head is a uniform light brown above. A wide, dark brown band extends from in front of the eye back along the side of the neck, becoming wider, and ending abruptly just in front of the shoulder. Bordering the brown band below is a narrow, cream line that passes from the posterior canthal scale back along the suboculars, through the ear, and ends at the insertion of the forelimb, and bordering it above is a wide, cream band that begins at the upper corner of the orbit and extends back on the neck and body as a paravertebral stripe, ending on the base of the tail. Usually three or four wide, dark brown, cream edged bands cross the back, constricted or interrupted where they cross the paravertebral light stripes. The tail has a dorsal series of dark brown, cream edged ovals. The limbs are light brown with a few bold, dark brown, cream edged bands or spots. The ventral surfaces are whitish, with three wide, grey stripes (one median, two lateral) that begin near the jaw symphysis and extend to the vent.

In both sexes the colour pattern is usually as described above. In some individuals the dark crossbands are lacking ; in others the light paravertebral stripes are lacking. I have seen no specimens in which both crossbands and stripes are absent.

REMARks. The holotype appears to have been stored for a time in strong preservative, or to have been partly desiccated. The extremities are somewhat shrivelled, and the subdigital lamellae appear wrinkled. The lamellae are, however, perfectly smooth surfaced, although in the type description they are said to be keeled.

Enyalius bilineatus has been known since Boulenger (I885b : I2I) under the name Enyalius fitzingeri. In the genus Laemanctus Wiegmann (I834:46) briefly described three Brazilian species : fitzingeri, undulatus, and obtusirostris, and gave a lengthy description of a fourth species, longiceps, from México. Duméril \& Bibron (I837 : 72-76) repeated the descriptions on Wiegmann's authority, and added a fifth species L. acutirostris. Fitzinger (I843) overlooked obtusirostris, but placed several additional species in Laemanctus : fitzingeri, undulatus, and vautieri were placed in the subgenus Urostrophus, with vautieri designated (p. I6) as the type of the subgenus. Gray (I845 : I84-I85) placed fitzingeri, undulatus, obtusirostris, and acutirostris under the genus Ecphymotes, basing his description entirely on Wiegmann. Boulenger (I885 $\mathrm{b}: \mathrm{I} 2 \mathrm{I}$ ) recognized fitzingeri and undulatus as species of Enyalius, and included obtusirostris in the synonomy of undulatus. On the following page he described a new species of Anisolepis, A. iheringii, but in the " addenda and corrigenda " (vol. 3 : 500-50I) undulatus was transferred to the genus Anisolepis, and A. iheringii was placed in its synonomy.

I have examined Wiegmann's holotypes of his species of Laemanctus, and find that those of fitzingeri (Z.M.B. 495), obtusirostris (Z.M.B. 496), and undulatus (Z.M.B. 497) are all of the same species, that which is presently known as Anisolepis undulatus. However, it is clear from Boulenger's characterization of Enyalius fitzingeri (and my examination of his specimens : B.M.N.H. Nos. 49.II.29.2 and 6I.5.2I.3) 
that the species to which he is referring is Enyalius bilineatus, which he included in the synonomy of $E$. catenatus.

RANGE. Enyalius bilineatus is known from the states of Espirito Santo and adjacent eastern Minas Gerãis, Brazil. E. catenatus, E. boulengeri, and E. bibronii all probably occur within the range of $E$. bilineatus (Fig. Io).

Specimens examined. Brazil: Minas Gerãis, Antônio Carlos M.C.Z. 84034 ; Minas Gerãis, Viçosa Muias M.V.Z. I494I ; Minas Gerãis, no specific locality M.C.Z. 5567 ; Espirito Santo, Santa Theresa, S.M.F. 24890 ; Espirito Santo, no specific locality N.M.W. I2968 (8 exs), S.M.F. II054, Z.M.H. 22I6 (I6 exs) ; between Espirito Santo and Minas Gerãis Z.M.H. 2206 (I3 exs), 2207 (9 exs) ; Ribeirão de Rapozo Z.M.K. 25 ; Lagoa Santa Z.M.K. 26-29; no specific locality M.H.N.P. 68I7 (holotype), B.M.N.H. 6I.5.2I.3, 49.II.29.2.

\section{Enyalius pictus (Wied)}

Agama picta Wied, I825, p. I25.

Ecphymotes pictus Fitzinger, 1826, p. 49.

Uraniscodon picta Kaup, I826, p. 9I.

Uraniscodon (Pneustes) picta Kaup, 1827, p. 612.

Hypsibatus picta Wagler, I830, p. I50.

Ophyessa Picta Gray, I83I, p. 40.

Calotes pictus Schinz, I835, p. 86, pl. 25, fig. 2.

Uperanodon pictum Duméril \& Bibron, I837, p. 25I.

Hypsibatus (Uperanodon) pictus Fitzinger, 1843, p. 48.

Uraniscodon pictum Gray, I845, p. 223.

Enyalius zonatus Wettstein, 1926, p. I.

Holotype. The holotype of Enyalius pictus has not been located but apparently was in the American Museum of Natural History, New York, and is now lost. In the files of the museum is a catalogue, dated I860, that lists all of the specimens of Wied acquired by the American Museum. The holotype of both Agama catenata and Agama picta are listed, but I can find no record of the latter ever having been catalogued into the American Museum's collection. The origin of the specimen is not specified, but Wied (I825: I29) later stated that specimens were found at Lago d'Arara and Mucurí, which, according to the map of Wied's journeys (Wied, I820) are in southeastern Bahía : Mucurí a town at the mouth of the Río Mucurí, and Lago d'Arara a few kilometres inland. I therefore propose that the type locality of Agama picta be restricted to Mucurí, southeastern Bahía, Brazil. A specimen in the Naturhistorischen Museum in Vienna (No. 13894) from " Mucuri dist." is here designated as the neotype of Agama picta Wied.

Characteristics. (Fig. 2). The dorsal head scales are smooth and moderately convex. The scales of the supraocular region are small laterally, enlarged centrally and medially, the largest about three-fourths to as large as the scales of the supraorbital semicircles. The distance between the nasal scale and the tip of the snout is slightly less than one-half the distance between the nasal and the anterior corner of the orbit. The orbit is bordered in front and below by an arc of nine or ten large 
scales, each with a median keel. The temporals are polygonal, smooth, and slightly convex.

A vertebral row of enlarged scales extends from the occiput to midway along the tail ; they are conical on the neck, arched and keeled along the back. The dorsal scales adjacent to the vertebral row are smooth, polygonal, juxtaposed, and of various sizes. Laterally they grade into smooth, rounded, strongly convex scales with very small, more or less triangular granules in the interspaces. The ventral scales are smooth, somewhat convex, and several times larger than the dorsals. Scale counts are given in Table $\mathrm{I}$.

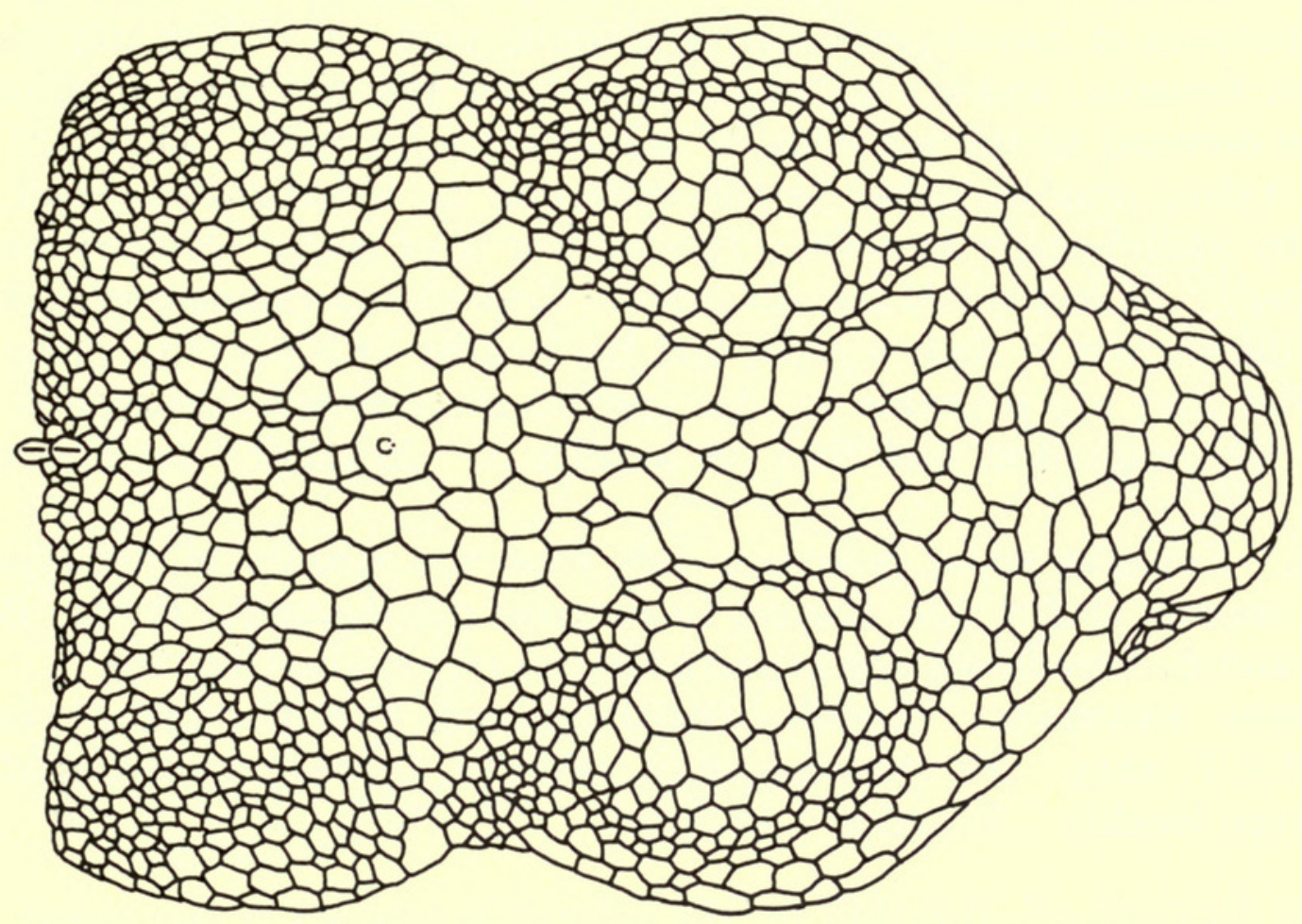

FIG. 2. Dorsal view of the head of Enyalius pictus (M.Z.T. No. 2243).

The tail is autotomic, but the caudal scales are arranged in irregular, poorly differentiated segments, usually with six or seven dorsal and three or four ventral scales in each segment (Fig. 9). Variation in snout-vent length to tail length ratios, and the maximum adult size for each sex are given in Table 2.

The subdigital lamellae are smooth and convex, the distal four or five lamellae of each digit medially divided. The fourth toe of the adpressed hind limb extends beyond the tip of the snout.

Colour in preservative : the head and anterior part of the neck is uniform grey. The back and posterior part of the neck are crossed by five wide, brown bands, the first of which is a rich, reddish-brown. Between the brown crossbands are narrow bands of grey, the first of which is conspicuously lighter than the others, almost white. The tail is marked with wide, brown bands, and the limbs with short, brown bars. The ventral surfaces are uniform white. The pattern is equally vivid in both sexes.

Remarks. The original description of Agama picta is detailed, and accompanied 
by an excellent coloured illustration, repeated by Schinz (I835: pl. 25, fig. 2). Its distinctive pattern somewhat resembles the pattern of Plica umbra, especially that of more brightly coloured juveniles. It is apparently this resemblance that led workers of the last century to associate the two species in the same or closely related genera. Boulenger (I885b : I79) placed Agama picta in the synonomy of Uraniscodon umbra, although he, and all authors since Wied, based their treatment of the species entirely upon the original description and illustration. Thus, Wied's Agama picta is here referred to the genus Enyalius for the first time.

In the Naturhistorischen Museum in Vienna are three specimens of Enyalius that correspond exactly to the description and illustration of Agama picta. Two of these are the syntypes of Enyalius zonatus (Wettstein, I926: I). They are said to have come from Ecuador, and are accompanied only by the additional information that they were donated to the museum by Steindachner in I905. The third specimen (N.M.W. I3894) was identified in the collection as Uraniscodon umbra, and was donated by Steindachner in I868. The locality label reads " Mucurí district, coll. Wertheimer ". The detailed resemblances of these three specimens with the description and illustration of Agama picta, and the locality of No. I3894, make it almost certain that they are referable to that species, even though the type is no longer available for comparison, and that the locality of "Ecuador" for E. zonatus is in error.

RANGE. Enyalius pictus is known only from the vicinity of the type locality, near the mouth of the Río Mucurí in extreme southeastern Bahía, Brazil. E. catenatus and $E$. bibronii may be expected in this region also (Fig. Io).

Specimens examined. Brazil: Bahía, Mucurí N.M.W. I3894; no specific locality M.Z.T. 2243. No specific locality: N.M.W. I7I88-9 (syntypes of Enyalius zonatus, type locality " Ecuador", in error).

\section{Enyalius bibronii Boulenger}

Enyalius bibronii Boulenger, I885b, p. II 9 .

Holotype. B.M.N.H. No. 69.II.3.8, from "Bahia ”, Brazil.

ChARACTERISTics (Fig. 3). The dorsal head scales are smooth and flat, or moderately convex. The supraoculars are small and numerous laterally, markedly enlarged medially, the largest about equal in size to the scales of the supraorbital semicircles. The distance between the nasal scale and the tip of the snout is less than one-half the distance between the nasal and the anterior corner of the orbit. The orbit is bordered in front and below by an arc of seven or eight large scales, each with a keel along its upper margin. The temporals are smooth and convex, polygonal and juxtaposed except just anterior to the tympanum, where they are rounded with tiny granules in the interspaces.

A vertebral row of enlarged scales extends back from the occiput to the base of the tail, conical on the neck, and arched and keeled along the back. The dorsal scales adjacent to the vertebral row are polygonal, juxtaposed, weakly and obtusely keeled, and of various sizes. Laterally they grade into smooth, rounded, somewhat 
convex scales with small, more or less triangular granules in the interspaces. The ventral body scales are several times larger than the dorsals, smooth, except on the chest were they may be faintly, obtusely keeled. Scale counts are given in Table I.

The tail is autotomic, and the caudal scales are arranged in segments, with six dorsal and three ventral scales in each segment (Fig. 9C). Variation in the snoutvent length to tail length ratio, and the maximum adult size for females (males unknown) are given in Table 2.

The subdigital lamellae are smooth and convex, the distal four or five lamellae of

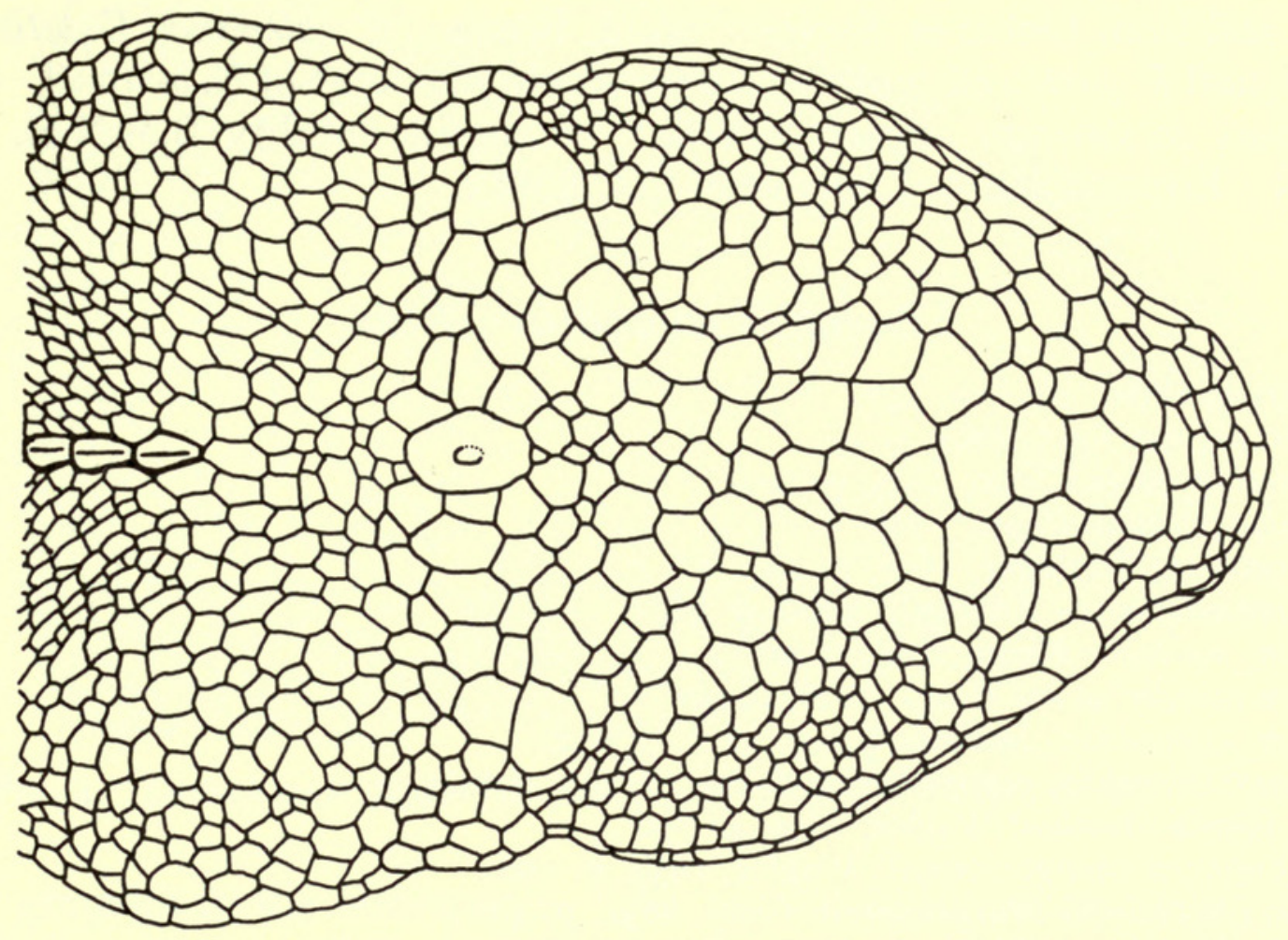

FIG. 3. Dorsal view of the head of Enyalius bibronii (B.M.N.H. No. 69.I I.3.8, holotype).

each digit medially divided. The fourth toe of the adpressed hind limb extends to the anterior corner of the orbit.

Colour in preservative : the species is known only from two females. The holotype is light greyish-tan above. A short, narrow, brown stripe extends from the eye to the posterior upper labial on each side. A brown $\sqsupset$-shaped mark is present on each side of the head between the orbit and tympanum. A small median, and a pair of larger lateral brown spots are present on the neck. Down the middle of the back is a series of alternating, squarish brown spots, each with a small, round, whitish spot in front and behind. The tail is banded with grey and brown, and the limbs with narrow brown bands. The ventral surfaces are uniform white. The other female has two brown bands across the supraocular region, a wide, dark brown stripe from the eye that extends back through the tympanum and ends abruptly just above the forelimb insertion, bordered below by a narrow, cream stripe. Down the middle of the back is a series of brown ovals, flanked on either side by a yellowish stripe. The undersurfaces are light, cream-yellow with numerous, dark brown spots. 
Remarks. Boulenger (I885b : II9) based Enyalius bibronii on a single specimen from Bahía. However, he listed Enyalius rhombifer (non Spix) of Duméril \& Bibron (I837 : 23I) as a synonym, and indicated the range as "Guianas and Brazil ". Three specimens formed the basis of Duméril \& Bibron's description of rhombifer. One of these is referable to $E$. brasiliensis, and the other two, from Cayenne, are of an unnamed species. Boulenger was apparently misled by the description of rhombifer as having smooth ventral scales ; I have examined Duméril \& Bibron's specimens, and the ventrals are definitely keeled.

RANGE. Enyalius bibronii is known only from an unspecified locality in the state of Bahía, and from Linhares, Espirito Santo, Brazil. E. catenatus, E. bilineatus, E. boulengeri, and E. pictus all probably occur within the range of E. bibronii. (Fig. Io).

Specimens EXAMINed. Brazil : Bahía ; no specific locality B.M.N.H. 69.II.3.8 (holotype) ; Espirito Santo, Linhares M.C.Z. 82873.

\section{Enyalius catenatus (Wied)}

Agama catenata Wied, I821, p. 247.

Lophyrus Rhombifer Spix, 1825, p. 9.

Lophyrus margaritaceus Spix, 1825, p. Io.

Lophyrus albomaxillaris Spix, I825, p. II.

Ophryessa catenata Fitzinger, 1826, p. 48.

Ophryessa margaritaceus Fitzinger, 1826, p. 48 .

Uraniscodon rhombifer Kaup, 1826, p. 90.

Uraniscodon margaritaceus Kaup, 1826, p. 90.

Uraniscodon (Ophryessa) catenata Kaup, I827, p. 6r2.

Uraniscodon (Ophryessa) margaritacea Kaup, I827, p. 612.

Enyalius [Agama catenata] Wagler, I830, p. I50.

Enyalius [Lophyrus margaritaceus] Wagler, I830, p. I50.

Oph. [yessa] (Xiphurus) Margaritaceus Gray, I831, p. 40.

Oph. [yessa] (Xiphurus) Rhombifer Gray, I831, p. 40.

? Oph. [yessa] (Plica) Braziliensis (non Lesson) Gray, I831, p. 40.

Hypsibatus (Enyalius) catenatus Fitzinger, I843, p. 57.

Hypsibatus (Enyalius) margaritaceus Fitzinger, 1843, p. 57.

Enyalius catenatus Boulenger, I885, p. II 8 .

Enyalius catenatus paulista Ihering, I898, p. I02.

Holotype. A.M.N.H. No. I08. The original description is given in a footnote in Chapter VII (vol. 2) of Wied's Reise nach Brasilien (I82I). The chapter is a daily account of Wied's journey from Conquista north to Salvador, the capital city of Bahía. The footnote occurs on page 247 which, together with the preceding page, is concerned with the fauna near Cabeça do Boi, a village just north of the Río das Contas in eastern Bahía. Cabeça do Boi may thus reasonably be considered the type locality.

Characteristics. (Fig. 4). The dorsal head scales are smooth and slightly convex on the snout and in the frontonasal region, faintly to moderately keeled in the frontal and supraocular regions. The supraoculars are small and numerous laterally, enlarged medially ; the largest supraoculars are about three-quarters to as large as the scales of the supraorbital semicircles. The distance between the nasal 
scale and the tip of the snout is about one-half the distance between the nasal and the anterior corner of the orbit. The orbit is bordered in front and below by an arc of Io or II enlarged scales, each with a median keel. The temporals are smooth or weakly keeled.

A vertebral row of enlarged scales extends from the occiput to the base of the tail ; they are conical on the neck, and arched and keeled along the back. The dorsal scales adjacent to the vertebral row are polygonal, juxtaposed, faintly keeled, and of various sizes. Laterally they grade into rounded, convex scales with more or less

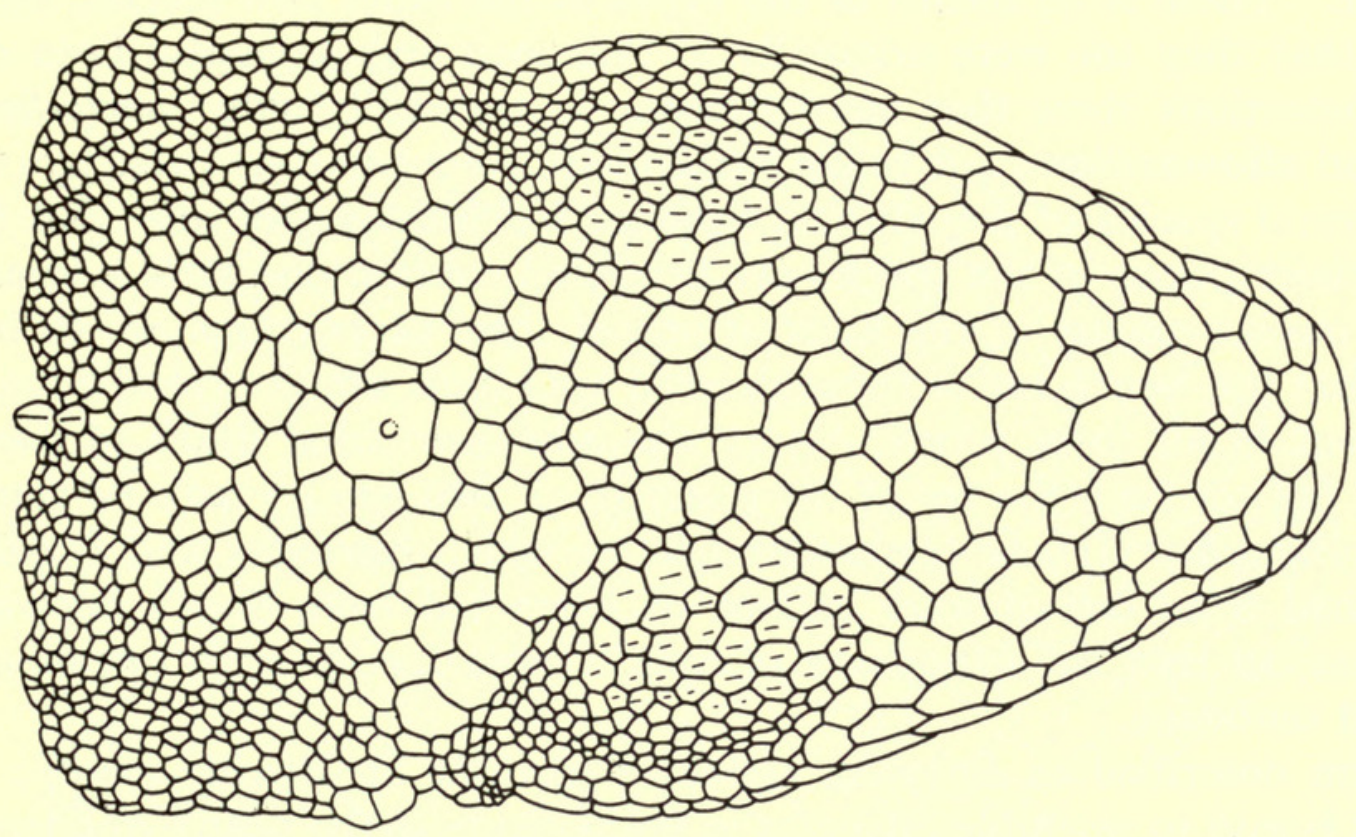

FIG. 4. Dorsal view of the head of Enyalius catenatus (M.C.Z. No. 7320).

triangular granules in the interspaces. The ventral scales are large and distinctly keeled. Scale counts are given in Table I.

The tail is autotomic, and the caudal scales are arranged in segments, with five dorsal and three ventral scale rows in each segment. Variation in the snout-vent to tail length ratios, and the maximum sizes of both sexes are given in Table 2 .

The subdigital lamellae are smooth and convex, the distal four or five lamellae of each digit medially divided. The fourth toe of the adpressed hind limb extends beyond the tip of the snout.

Colour in preservative : males are almost uniform brownish, or grey-green, with a dark grey throat and whitish venter ; rarely they have obscure markings on the side of the body and limbs. Females almost always have a bold pattern. A pair of wide, cream-coloured paravertebral stripes may be present from the head to the base of the tail. A row of large, dark brown, cream-edged diamonds may be present down the middle of the back and onto the tail, or a median row of alternating triangular brown spots down the middle of the back may produce a zig-zag pattern. Narrow, cream-coloured, dark brown edged, oblique bands may be present on the sides of the body. A brown crossband may be present on the top of the head, and narrow brown bands may be present on the sides of the head. The tail and limbs may have brown bands. Any one of these markings, or any combination of them, may be 
present. Rarely, the female is nearly uniform dark brown, with a few irregular cream-coloured spots. The ventral surfaces are usually yellowish with irregular brownish markings.

Remarks. The three species described by Spix (I825), listed in the synonomy above, are probably all referable to Enyalius catenatus, but the types of these forms have been lost or destroyed. Records in the Zoologisches Staatsammlung des Bayerischen Staates in München indicate that the type of Lophyrus rhombifer was present in that museum prior to World War II, but was destroyed during the course of the war. There is no record of the types of the other two species, but it seems probable that they too were originally in München and have also been destroyed. Spix's illustrations show that margaritaceus in an adult male, rhombifer an adult female, and albomaxillaris a juvenile female with colour patterns that are characteristic of several species of Enyalius : catenatus, brasiliensis, iheringii, and boulengeri. The text descriptions of the species are brief and contain no useful measurements ; however, measurements of the illustrations, if their proportions are to be trusted, indicate that the fourth toe of the adpressed hind limb would extend beyond the tip of the snout in all three forms. Since the adpressed hind limbs of iheringii and boulengeri fail to reach the tip of the snout these two species may be eliminated as possible synonyms. Those characteristics by which catenatus and brasiliensis are distinguished from one another cannot be extracted from Spix's description and illustrations, so that the synonomy of Spix's three species with catenatus must be considered tentative.

The form described as Enyalius catenatus paulista by Ihering (I898: 102) from São Paulo is said to resemble catenatus in the position of the nostril and length of the tibia, but to be intermediate between catenatus and iheringii in pattern. In view of the extreme variation in pattern in both catenatus and iheringii it would seem best at present to regard paulista as merely a colour variant of catenatus.

RANGE. Enyalius catenatus occurs in eastern Brazil from the state of Pernambuco in the north at least as far south as the state of Santa Catarena ; a record from Buenos Aires, Argentina seems questionable. A record from an unspecified locality in the state of Goiás indicates that the species may occur some distance inland. Apparently E. catenatus overlaps the ranges of all other species of Enyalius except leechii.

Specimens examined. Brazil: Pernambuco, Iguaraçú B.M.N.H. 88.4.I8.5 ; Pernambuco, Recife S.M.F. 60337 ; Pernambuco, no specific locality Z.S.B.S. 934/I920 ; Bahía, near Cabeça do Boi A.M.N.H. I08 (holotype) ; Bahía, no specific locality B.M.N.H. 69.II.3.7, 6I.3.23.3, N.M.W. I2954-5, I4075, I8I68, Z.S.B.S. 2743/o, S.M.F. II040 ; Goiás, no specific locality M.C.Z. 425I ; Rio de Janeiro, Porto Real B.M.N.H. 87.I2.29.I-2 ; Rio de Janeiro, Guanabaro, Repressa Rio Grande C.A.S. 96876 ; Rio de Janeiro, Barao Homen de Mello Itatiaya S.M.F. 362I7 ; Rio de Janeiro, Petrópolis M.C.Z. 7320 ; Rio de Janeiro, no specific locality M.C.Z. 37I7, U.S.N.M. 98603 ; Paraná, Sitio Cafezal, km 92 on São Paulo Rd., Curitiba S.M.F. 64697 ; Santa Catarena, Theresopolis B.M.N.H. 93.9.30.I ; Espirito Santo, Rio Doce S.M.F. I25II-2 ; no specific locality B.M.N.H. 5I.7.I7.8., 57.I.II.20, xiii 28b. Argentina : Buenos Aires Z.M.H. I008I (8 exs). South America : no specific locality Z.S.B.S. $503 / 0$. 


\section{Enyalius iheringii Boulenger}

Enyalius iheringii Boulenger, I885b, p. 192.

Syntypes. B.M.N.H. 82.I0.4.48-49 from " Rio Grande do Sul ”, Brazil.

Characteristics. (Fig. 5). The dorsal head scales are smooth on the snout, convex and obtusely keeled on the frontal and supraocular regions. The supraoculars are small and numerous laterally, and enlarged medially, the largest equal to or a little smaller than the scales of the supraorbital semicircles. The nasal scale is

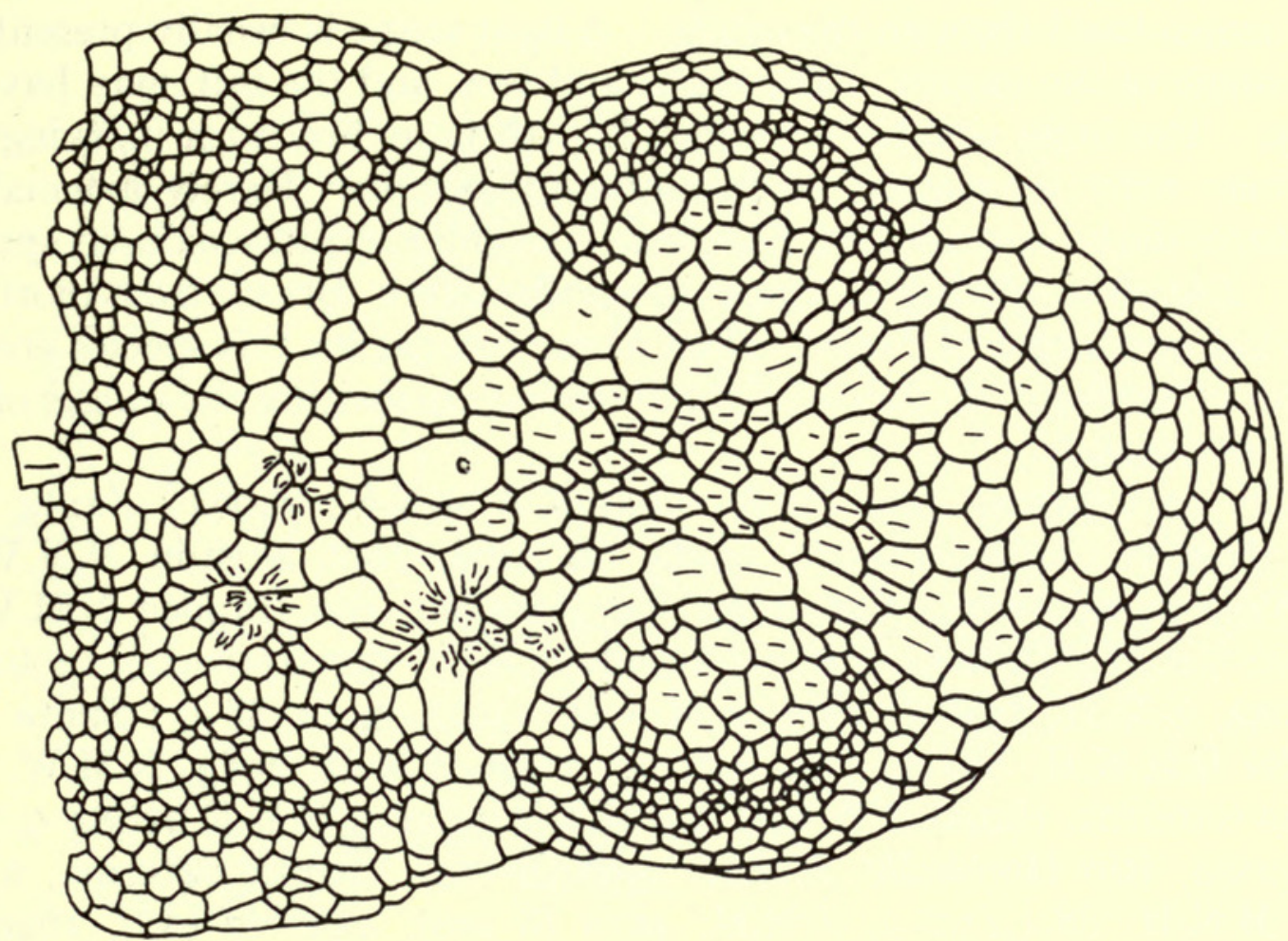

FIG. 5. Dorsal view of the head of Enyalius iheringii (B.M.N.H. No. I946.8.9.4, syntype).

about midway between the tip of the snout and the anterior corner of the orbit. The orbit is bordered in front and below by an arc of about ten large scales, each with a median keel. The temporals are polygonal, juxtaposed, and smooth.

A vertebral row of enlarged scales extends from the occiput to the base of the tail ; they are conical on the neck, and arched and keeled along the back. The dorsal scales adjacent to the vertebral row are polygonal, juxtaposed, obtusely keeled, and of various sizes. Laterally they grade into rounded, obtusely keeled, convex scales with more or less triangular granules in the interspaces. The ventral scales are large and distinctly keeled. Scale counts are given in Table I.

The tail is not autotomic, and the caudal scales are arranged irregularly without a trace of segmentation. Variation in the snout-vent to tail length ratios, and the maximum adult sizes of both sexes are given in Table 2 .

The subdigital lamellae are smooth and convex, or may have one or two indistinct keels. The distal four or five lamellae are medially divided. The fourth toe of the adpressed hind limb extends to about the middle of the orbit. 
Colour in preservative : males usually are almost uniform brownish or greyish-green above, the throat dark grey, and the belly whitish. Rarely males have indistinct markings similar to the females.

The pattern in females is highly variable, but almost always there is some type of vivid pattern. Often a pair of wide, cream-coloured stripes extend from the paraoccipital region of the head to the base of the tail. A middorsal series of large, brown rhombs may be present, or a series of alternating triangles form a zig-zag stripe down the middle of the back. On the sides of the body there may be narrow, oblique light lines, bordered posteriorly by dark brown. The top of the head is sometimes crossed by a dark brown band through the orbits. A light stripe is usually present from the eye to the angle of the mouth. The limbs and feet, and the tail, may have narrow, cream bars. The belly usually is yellowish with faint brownish markings. These markings may exist separately, or in any combination. Rarely a female will be nearly uniform dark brown with a few small, irregular, cream-coloured spots.

RANGE. Enyalius iheringii occurs in southeastern Brazil from northern Rio Grande do Sul north to São Paulo. Most of the records for this species are from the state of Santa Caterina. E. iheringii apparently occurs within the ranges of E. catenatus and $E$. brasiliensis.

Specimens examined. São Paulo, Osasco A.M.N.H. 74964 ; Santa Caterina, Blumenau N.M.W. I4947, I2958 ; Santa Caterina, New Bremin N.M.W. I2967, S.M.F. 24833, 30303 ; Santa Caterina, Dist. Jaragúa, Rio Itapocú N.M.W. I2964, Z.M.H. 2862 (5 exs) ; Santa Caterina, Joinville N.M.W. I2966 (I6 exs), I296I (I7 exs), S.M.F. II052, Z.M.H. 4536 (7 exs), F.M.N.H. II622-3, II388-9 ; Santa Caterina, Theresopolis B.M.N.H. 88.9.2I.2-3, S.M.F. I1050, Z.M.H. 2683, N.M.W. I2960 (6 exs) ; Santa Caterina, Hansa B.M.N.H. I928.II.5.I09-II3, S.M.F. 24884-9, II042-8 ; Santa Caterina, Rio Humboldt Z.M.H. 3566 (6 exs) ; Santa Caterina, no specific locality B.M.N.H. 88.4.23.I-2, Z.M.H. 45I2 (8 exs), 4536 (7 exs), I649 (3 exs), U.S.N.M. 402I4-5 ; São Paulo, Iguape N.M.W. I2957 ; Rio Grande do Sul, Pôrto Alegre Z.M.K. I37 ; Rio Grande do Sul, no specific locality N.M.W. I4077, B.M.N.H. 82.I0.448-9 [RR I946.8.9.3-4] (syntypes) ; São Paulo, Santos N.M.W. I2959, I2963 ; Ribeirão Pires Z.S.B.S. 933/I920 ; Taragua N.M.W. I2964 ; no specific locality S.M.F. II04I, Z.M.K. I33-6, I38, U.S.N.M. 58423.

\section{Enyalius brasiliensis (Lesson)}

Lophyrus brasiliensis Lesson, I828, p. 32, pl. I, fig. 3.

Enyalius rhombifer Duméril \& Bibron (part), 1837, p. 231.

Syntypes. M.H.N.P. 68I6 (2 exs), from " Sainte-Catherine du Brésil ".

Characteristics. (Fig. 6). The dorsal head scales are smooth and nearly flat on the snout, convex and keeled in the frontal, prefrontal, and supraocular regions. The supraoculars are small and numerous laterally, and only slightly enlarged medially, the largest about three-fourths as large as the scales of the supraorbital semicircles. The nasal scale is slightly closer to the tip of the snout than it is to the anterior corner of the orbit. The orbit is bordered in front and below by an arc of 
nine or ten enlarged scales, each with a median keel. The temporals are polygonal, smooth, and convex.

A vertebral row of enlarged scales extends from the occiput to the base of the tail ; they are conical on the neck, and arched and keeled along the back. The dorsal scales adjacent to the vertebral row are smooth or faintly keeled, polygonal, juxtaposed, and of various sizes. Laterally they grade into rounded, strongly convex scales with more or less triangular scales in the interspaces. The ventral scales are large, distinctly and rather sharply keeled on the chest, less strongly keeled on the belly. Scale counts are given in Table I.

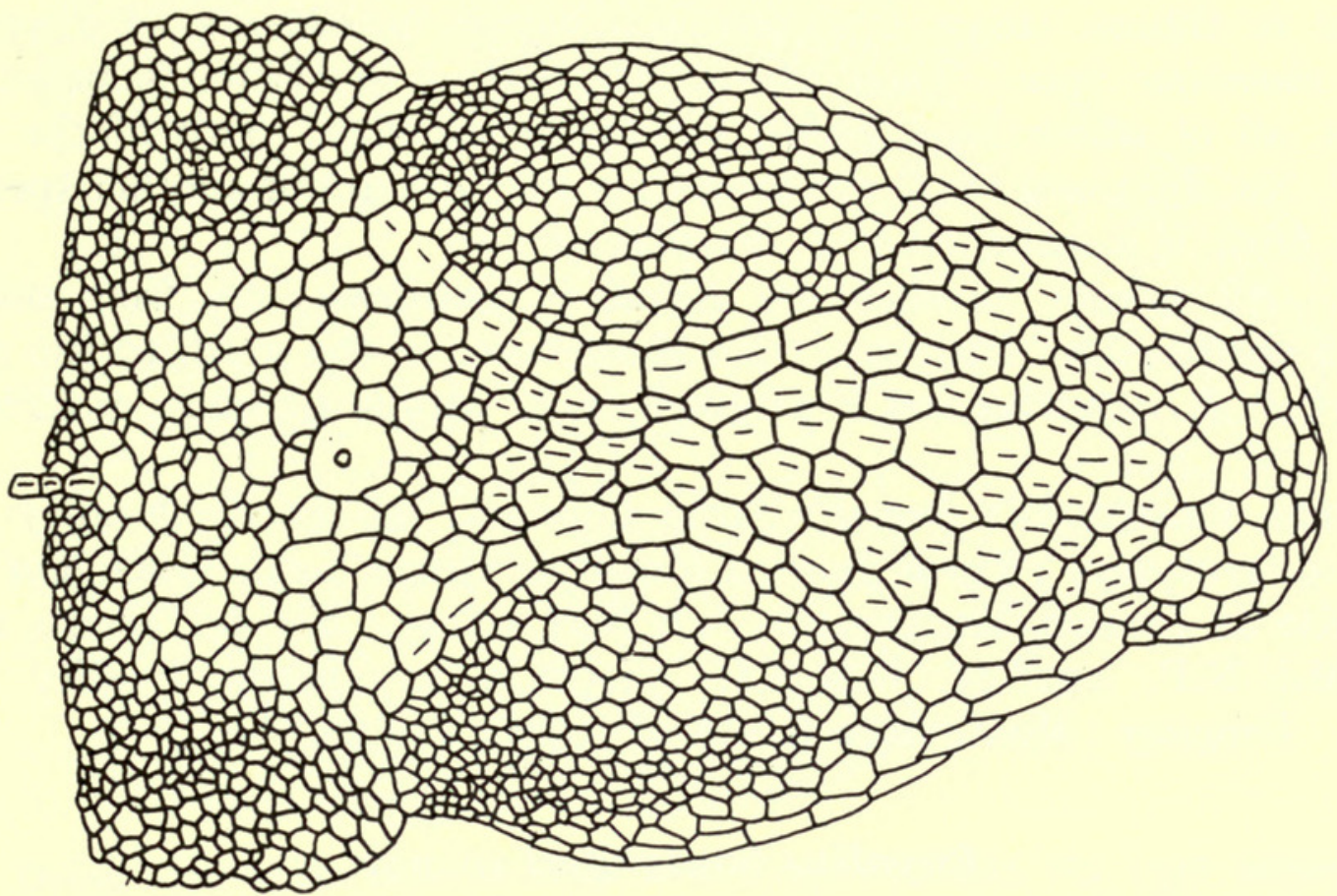

FIG. 6. Dorsal view of the head of Enyalius brasiliensis (B.M.N.H. No. I923.I2.4.38).

The tail is autotomic, and the caudal scales are arranged in segments, with five dorsal and three ventral scales in each segment. Variation in the snout-vent length to tail length ratios, and the maximum sizes of both sexes are given in Table 2 .

The subdigital lamellae are sharply keeled, usually with three keels on each lamella. A median division of the distal lamellae is absent, or only faintly indicated. The fourth toe of the adpressed hind limb extends beyond the tip of the snout.

Colour in preservative: females are dark, chestnut brown above, with a pair of wide, cream-coloured paravertebral stripes and/or a series of rather large, dark brown diamonds edged in cream down the middle of the back. A darker brown band crosses the top of the head through the orbits, and another extends from the eye to the posterior upper labials, and another extends back on the temporal region from the eye through the tympanum, thence widening on the side of the neck. The upper surfaces of the limbs have short, brown bands. The tail is indistinctly banded. Ventral surfaces of the body and limbs are yellowish, rather heavily marked with small, irregular brown spots. 
Males are dark purplish-grey above, the venter is dirty white, the gular region dark grey, and the ventral surfaces of the limbs have indistinct darker markings.

REMARKs. The description of Lophyrus brasiliensis is brief and includes no information that would permit one to definitely assign it to the genus Enyalius. The illustration (Lesson, I828 : pl. I, fig. 3) is that of a rather slender, long-tailed lizard, dark purple above, light blue below, with bold, white spots on the chin and belly. The syntypes, although not listed by Guibé (I959), still exist in the Paris Museum. The larger of the two appears to be the specimen illustrated by Lesson : the supraocular region on the left side is mashed down in a peculiar way that is reproduced exactly in the illustration.

Duméril \& Bibron (I837 : 23I) listed Lophyrus brasiliensis as a synonym of Enyalius rhombifer Spix. Their characterization of the latter is based on three specimens, all of which have keeled subdigital lamellae. Two of the specimens (M.H.N.P. No. 2373 and 68I5) are from Cayenne, and are of another species. The third, No. 68I4, is a specimen of E. brasiliensis.

RANGE. All specific localities for Enyalius brasiliensis are from southeastern Brazil and northeastern Uruguay, from Montevideo in the south to Rio de Janeiro in the north. E. catenatus and E. iheringii occur within the range of E. brasiliensis (Fig. Io).

Specimens examined. Brazil : Santa Caterina, no specific locality M.H.N.P. 68r6 (2 exs) (syntypes) ; Rio de Janeiro, Massif de Tijuca, Serra dos Orgãos M.H.N.P. 02.368 ; Rio de Janeiro, Mangaratiba A.M.N.H. 62I43 ; Rio de Janeiro, no specific locality M.H.N.P. I9I8.25, B.M.N.H. 74.5.2I.5 no specific locality B.M.N.H. xxiii.28c. Uruguay : Montevideo B.M.N.H. I923.I2.I4.38.

\section{Enyalius boulengeri sp. nov.}

Enyalius rhombifer (part) Duméril \& Bibron, I837, p. 23 I.

Holotype. Z.M.H. No. I338. An adult female from the state of Espirito Santo, Brazil; one of a series of $I_{5}$ specimens with the same data as the holotype received from a Mr. Michaelis on May 3, I898.

Diagnosis. E. boulengeri differs from E. bilineatus, E. pictus, E. bibronii, and $E$. iheringii in having distinctly keeled subdigital lamellae, and the distal lamellae not medially divided. Compared with those species of Enyalius with keeled subdigital lamellae, $E$. boulengeri differs from $E$. brasiliensis in having fewer vertebral scales and fewer midbody scales (see Table I), a shorter tail (see Table II), and shorter hind limbs, and differs from $E$. leechii in having smaller supraoculars, shorter hind limbs, less distinctly keeled head scales, and, possibly, in having a vertebral crest.

DESCRIPTION OF THE holotype. (Fig. 7). The dorsal head scales are convex, especially in the frontonasal region, and keeled in the supraocular and parietal regions. The supraoculars are small laterally, becoming only slightly enlarged medially ; the largest supraoculars are about one-third as large as the largest scales of the supraorbital semicircles. The nasal scale is about equal distance between the tip of the snout and the anterior corner of the orbit. The orbit is bordered below by 
an arc of eight enlarged scales, each with a median keel. The temporals are strongly convex and weakly keeled.

A vertebral row of enlarged scales extends from the occiput to the base of the tail ; they are conical on the neck, and arched and keeled along the back. There are 32 vertebral scales counted from the occiput to a line even with the anterior margins of the thighs held at right angles to the trunk.

The dorsal scales adjacent to the vertebral row are polygonal, juxtaposed, faintly and obtusely keeled, and of various sizes. Laterally they grade into smaller,

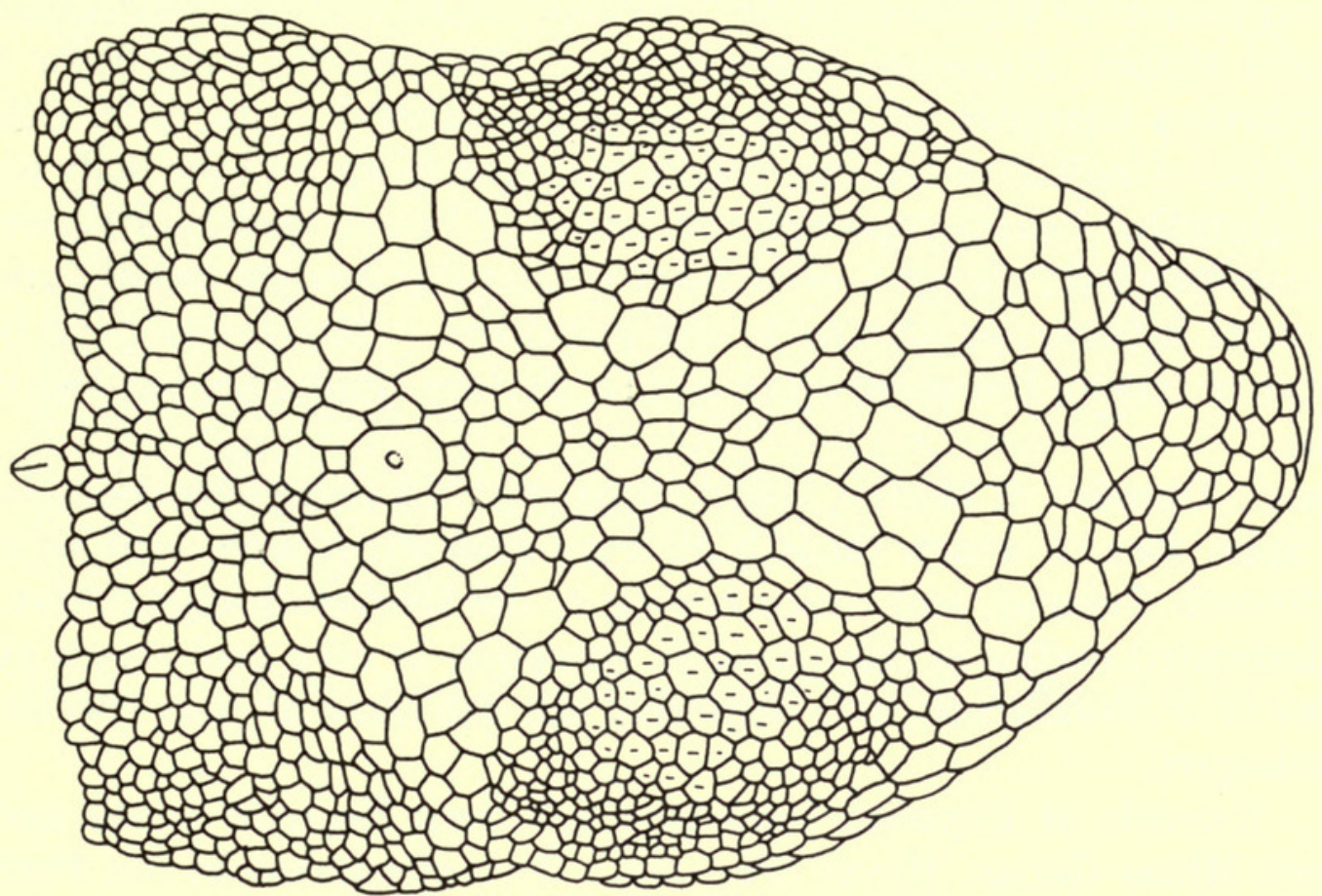

FIG. 7. Dorsal view of the head of Enyalius boulengeri (Z.M.H. No. I338, holotype).

rounded, convex scales with more or less triangular granules in the interspaces. The ventral scales are about three times as large as the dorsals, subimbricate, and distinctly keeled. There are I26 paravertebral scales counted as are the vertebral scales, and I36 scales around the middle of the body midway between the limb insertions.

The tail is autotomic, and the caudal scales are arranged in segments, with five dorsal and three ventral scales in each segment. The snout-vent length is Io8.6 $\mathrm{mm}$., the tail length $\mathrm{I} 83.0 \mathrm{~mm}$.

The subdigital lamellae have three or four sharp keels. The distal lamellae of each toe are not divided medially. The fourth toe of the adpressed hind limb extends to the anterior margin of the orbit.

The head is uniform dark brown above and on the sides. Down the middle of the back is a wide, zig-zag stripe of dark brown, formed by alternating triangles. Flanking the median zig-zag on each side is a wide paravertebral stripe of creamy yellow, flecked with brown, extending from just behind and above the tympanum to the base of the tail. The sides of the neck and body below the light paravertebral stripes are dark brown with indistinct lighter markings. The upper surfaces of the limbs are dark brown with irregular yellowish spots. The ventral surface of the 
body and limbs is light yellowish-tan with scattered small, brown spots ; the throat is slightly darker than the belly. The tail is yellowish-tan with irregular brown spots.

VARIATION. A total of 48 have been examined. Of these, 22 females and 7 males are sufficiently well preserved to provide accurate scale counts and measurements. The maximum snout-vent lengths in both sexes, and variation in the snout-vent length to tail length ratios are given in Table 2 . Variation in the vertebral, paravertebral, and midbody scale counts are given in Table $\mathrm{I}$.

The colour pattern is highly variable. Females have a pair of wide, creamy-yellow paravertebral stripes, a median series of large, dark brown rhombs or a series of alternating brown triangles that form a zig-zag vertebral stripe as in the holotype. The tail and limbs may have creamy-yellow bands or spots, and the belly is yellowishtan, and often rather heavily marked with irregular brown spots. In about one-half of the females examined the paravertebral stripes and/or median rhombs are restricted to, or are most intense on, the neck and shoulders. The males may be uniform greyish-green or brown, but more often have a pattern similar to, but less vivid than, the females.

REMarks. Duméril \& Bibron (I837 : 23I) referred three specimens to Enyalius rhombifer Spix, two of which (M.H.N.P. 2373 and 68I5) were said to come from Cayenne (French Guiana), and which belong to the species described here as boulengeri. As indicated earlier in this paper E. rhombifer is very probably a synonym of $E$. catenatus or E. brasiliensis, but definitely not the same as that species described here as boulengeri.

RANGE. Records of Enyalius boulengeri are from Espirito Santo and adjacent southeastern Minas Gerias, Brazil (Fig. Io). Two specimens in the Paris Museum are said to come from French Guiana, but this record seems doubtful. E. boulengeri probably occurs within the ranges of E. catenatus, E. bilineatus and E. bibronii, and possibly E. pictus.

Paratypes. Brazil : Espirito Santo, Chaves M.C.Z. 79025 ; Espirito Santo, no specific locality Z.M.H. I338 (holotype), 22I7 (I4 exs), N.M.W. I2956 (I3 exs) ; between Minas Gerais and Espirito Santo Z.M.H. 2205 (I5 exs) ; Minas Gerais, Santa Leopoldina Z.M.H. 2546 (2 exs). Cayenne (possibly in error) : no specific locality M.H.N.P. 2373, 68I5.

\section{Enyalius leechii (Boulenger)}

Enyalioides leechii Boulenger, 1885 b, p. 473.

Holotype. B.M.N.H. 86.I0.I4.I [RR I946.8.9.7], from “ Santarem ”, Brazil.

Characteristics. (Fig. 8). The dorsal head scales anterior to the parietal region are distinctly unicarinate ; those posterior to the parietal region and in the temporal region are smooth and convex. The supraoculars are small and numerous peripherally, enlarged centrally, the largest a little smaller than the scales of the supraorbital semicircles. The distance between the nasal scale and the tip of the snout is a little less than one-half the distance between the nasal and the anterior 


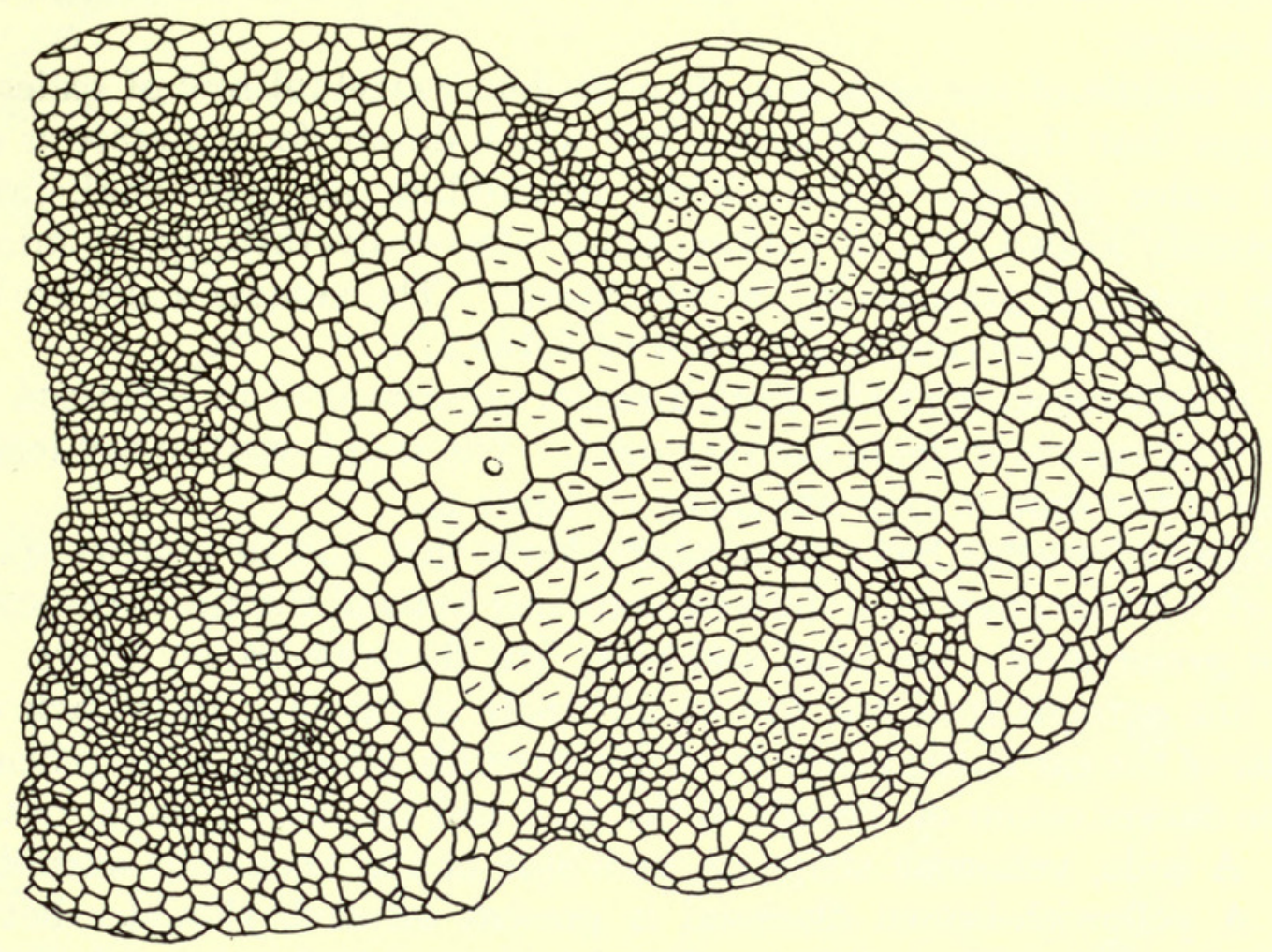

FIG. 8. Dorsal view of the head of Enyalius leechii (B.M.N.H. No. I946.8.9.7, holotype).

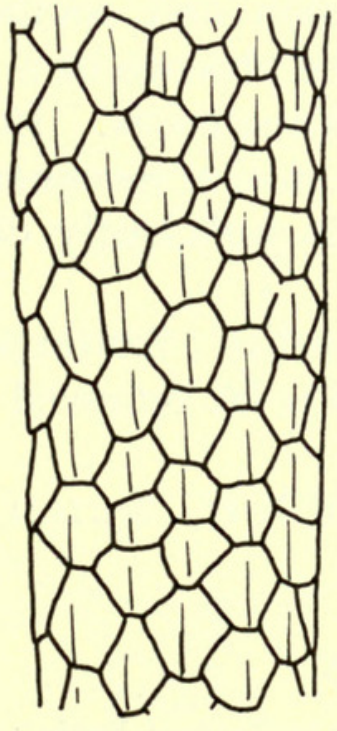

A

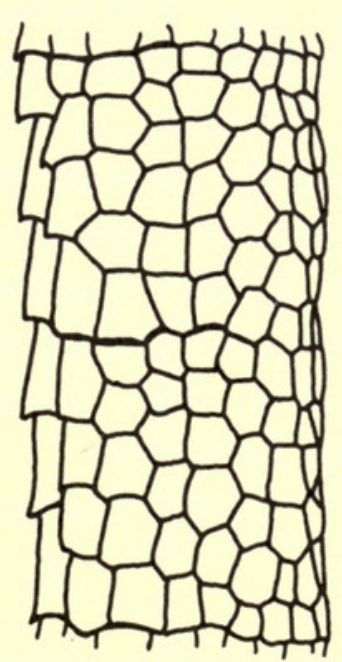

B

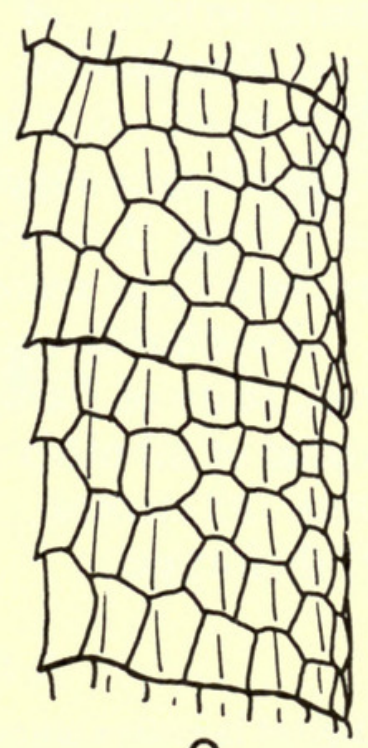

C

FIG. 9. Lateral view of the midsection of the tail of Enyalius bilineatus (A), E. pictus (B), and E. bibronii (c). 
corner of the orbit. The orbit is bordered in front and below by an arc of I4 scales, each of them arched and with a median keel. The temporals are polygonal, juxtaposed, and convex.

Along the middle of the back is a discontinuous vertebral row of scales that are scarcely larger than the adjacent scales, and which do not form a crest or serration. The dorsal scales adjacent to those along the midline are polygonal, juxtaposed, convex, obtusely keeled, and of various sizes. Laterally these grade into smaller, more or less triangular granules in the interspaces. The ventral scales are large and distinctly keeled. Scale counts are given in Table I.

The tail is autotomic, and the caudal scales are arranged in segments with five dorsal and three ventral scales in each segment. The snout-vent to tail length ratio, and the size of the unique type are given in Table 2.

The subdigital lamellae have three sharp keels that end in a short spine. The fourth toe of the adpressed hind limb extends just beyond the tip of the snout.

Colour in preservative : the head and body are chestnut-brown above. A faint, thin, dark line extends from the eye to the angle of the jaw, then back along the lower border of the ear to the insertion of the forelimb, effecting a sharp demarcation between the darker colour of the side of the neck and the lighter colour of the throat and chin. A wide, yellowish stripe on each side of the neck ends abruptly at the shoulder. A yellowish-brown diamond is present on each shoulder between the paravertebral stripes. The tail has a dorsal and a ventral series of brown, creamedged ovals, some of which are confluent on the sides. The limbs have indistinct dark crossbands. The venter is yellowish, unmarked except for a pair of oblique brown lines on the throat. As yet no males are known for this species.

REMARKs. Although Boulenger (I885b : 473) placed this species in Enyalioides, it has none of the distinguishing characteristics of that genus, but has all of the generic characteristics of Enyalius (see following discussion and comparison of Enyalius and Enyalioides). Its most peculiar feature is the absence of a vertebral crest, present in all other species of Enyalius, as well as in Enyalioides. In the type description Boulenger suggested that the absence of a crest in this specimen may be anomalous. Even if a crest is normally present, leechii is sufficiently distinct in other characters to be recognized as a valid species.

RANGE. Enyalius leechii is known only from the type locality : Santarem, on the Rio Amazon, state of Pará, Brazil (Fig. Io). This locality is far removed from the known records of all other species of Enyalius.

Specimens EXAmined. Brazil : Pará, Santarem B.M.N.H. 85.Io.I4.I [RR I946.8.9.7] (holotype).

\section{A Key to the Species of ENYALIUS}

I All subdigital lamellae smooth, or some of them with one or two indistinct keels ; the distal 4 or 5 lamellae of each digit with a median, longitudinal groove . .

- All subdigital lamellae distinctly keeled ; the distal 4 or 5 lamellae without a median groove, or the groove obscured by the keels

2 Dorsal head scales, including those on the snout, distinctly keeled; vertebral crest absent?

- Scales on the snout smooth, other dorsal head scales smooth or keeled ; vertebral 


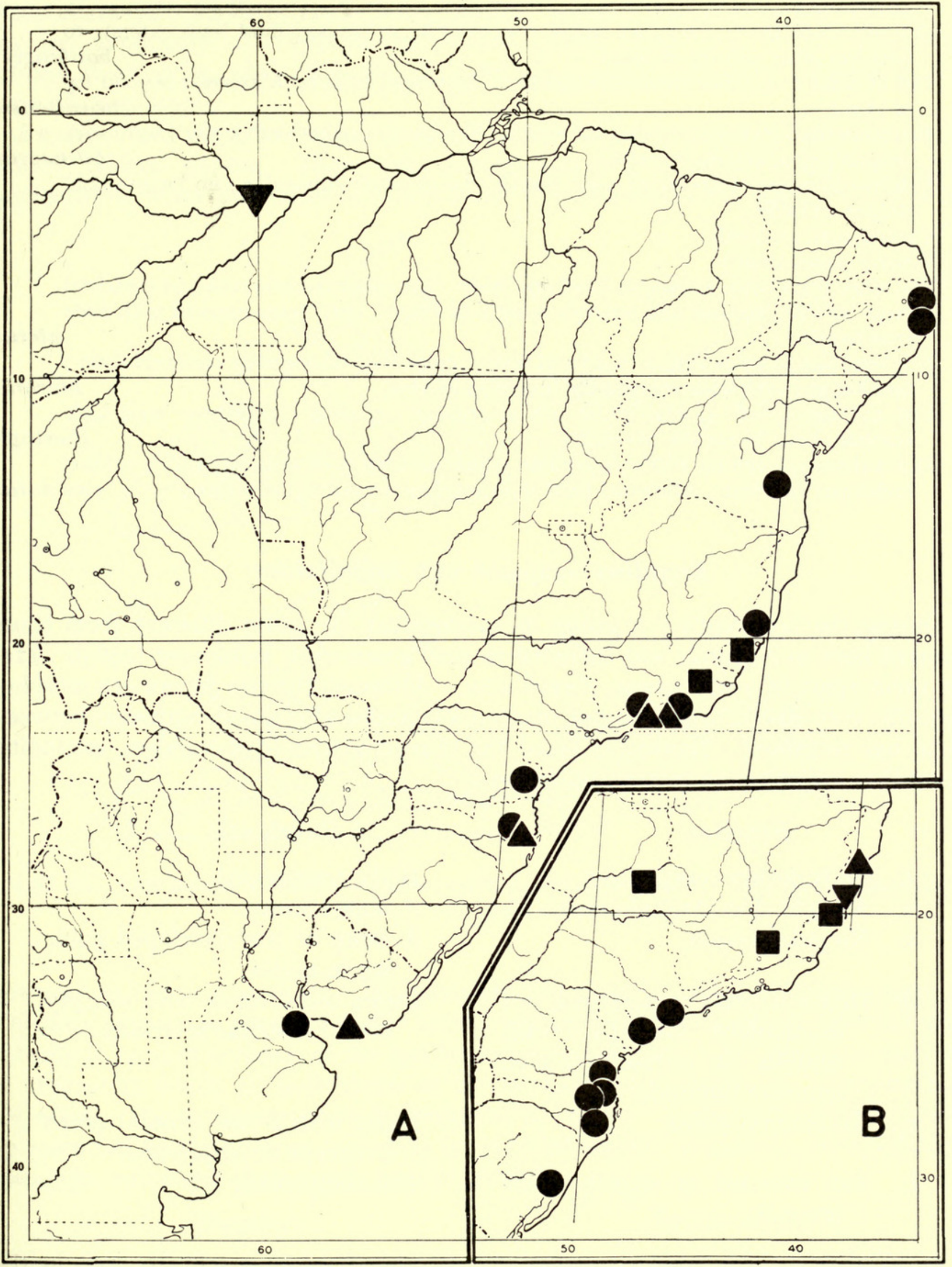

FIG. Io. Maps of eastern South America showing localities for Enyalius : A. E. catenatus (circles), E. boulengeri (squares), E. brasiliensis (triangles), and E. leechii (inverted triangle); B. E. bilineatus (squares), E. iheringii (circles), E. bibronii (triangles), and E. pictus (inverted triangle). 
crest present

3 Tail not more than $\mathrm{I} \cdot 92$ times snout-vent length; adpressed hind limb extends to between orbit and tip of snout

boulengeri

- Tail at least $2 \cdot 04$ times snout-vent length ; adpressed hind limb extends beyond tip of snout

brasiliensis

4 Tail more than 2.5 times snout-vent length ; usually an elongate subocular ; belly with three longitudinal dark stripes

bilineatus

- Tail less than 2.5 times snout-vent length ; no elongate subocular ; no longitudinal stripes on belly .

5 Ventral scales smooth

- Ventral scales keeled

6 Tail more than twice as long as head and body ; not more than 60 scales in vertebral crest between occiput and anterior margin of thigh ; both sexes marked with wide crossbands

- Tail less than twice as long as head and body ; more than 60 scales in vertebral crest ; females not with wide crossbands (males unknown).

pictus

7 Tail not autotomic, caudal scales not in regular segments; adpressed hind limb reaches about to middle of orbit

bibronii

- Tail autotomic, caudal scales in regular segments with 5 or 6 dorsal and 3 ventral scales per segment; adpressed hind limb reaches beyond tip of snout .

catenatus

\section{Enyalius compared with Enyalioides}

During the last century a group of species that are quite different from those referred here to Enyalius was included in that genus until Boulenger (I885b : II2) set them apart in a new genus, Enyalioides. Although the two genera are morphologically very distinct, and do not overlap geographically, some confusion between them has remained. Boulenger listed the characteristics of the genera, excluding those that are common to both, as follows:

\section{Enyalius}

a. Body feebly compressed

b. A slight dorsonuchal crest

c. No gular pouch

d. Digits scarcely compressed, not denticulate laterally, with smooth or obtusely keeled lamellae inferiorly

e. No femoral pores

f. Tail rounded or slightly compressed

\section{Enyalioides}

Body compressed

A dorsal crest

A more or less developed gular sac in males

Digits compressed, with sharply keeled lamellae inferiorly

Males with a few femoral pores (? except in palpebralis)

Tail compressed

In addition to proposing the genus Enyalioides, Boulenger $(1885 \mathrm{~b}: 473)$ in the same work described a new species, Enyalioides leechii. Apparently he considered sharply keeled subdigital lamellae to be the most significant character distinguishing Enyalioides from Enyalius, for leechii, which has keeled lamellae, corresponds in all 
other characteristics listed above with Enyalius. Gans \& Vanzolini (I954), in suggesting the synonomy of Enyalius coerulescens (Cope, I876: I69) with Enyalioides laticeps (Guichenot, I855:20), also stressed the presence of keeled lamellae in the type of coerulescens.

Enyalius and Enyalioides are unquestionably distinct, and probably not very closely related genera. There are several major osteological differences, and numerous external differences between them. The keeling of the subdigital lamellae,

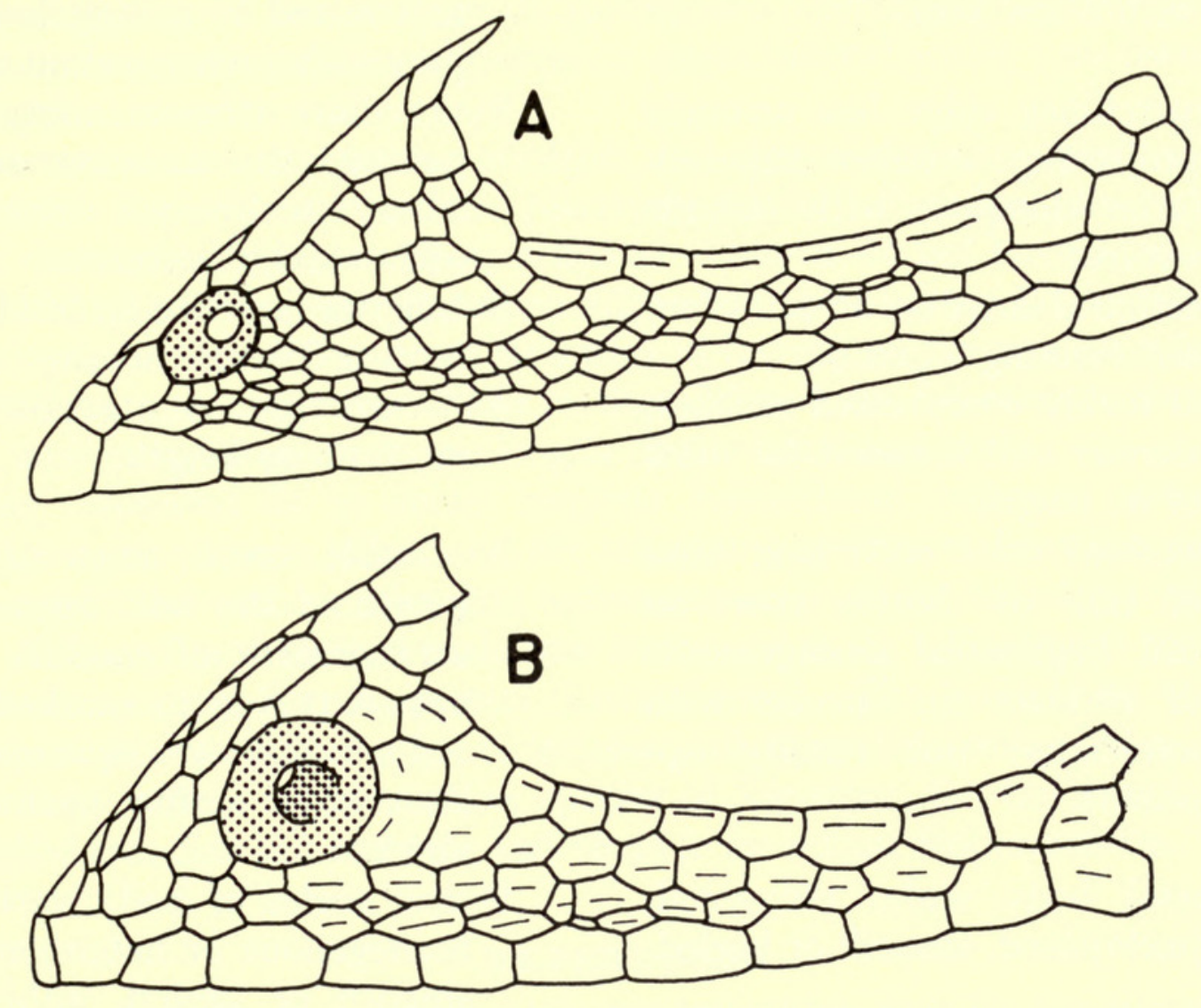

FIG. II. Left lateral view of the snout region of Enyalius catenatus (A), and Enyalioides praestabilis (в). The nasal scale is stippled.

however, is not one of them. The lamellae are sharply keeled in three species of Enyalius, smooth or obtusely keeled in one, and smooth in four others. Enyalioides is badly in need of revision at the species and subspecies level, but there is a number of characters which all individuals of the genus have in common, as opposed to Enyalius. The two genera may be compared as follows : (data on Enyalioides based on examination of all forms, including types of heterolepis, mocquardi, festae, laticeps, planiceps, microlepis, palpebralis, and praestabilis).

\section{Enyalius}

a. Nasal scale small, its diameter about one-fifth the distance between orbit and tip of snout; convex, with the

\section{Enyalioides}

Nasal scale very large, its diameter almost one-third the distance from orbit to tip of snout; convex in front of 


\section{Enyalius}

nostril directed laterally ; 4 or 5 scales between nasal and anterior corner of orbit (Fig. II).

b. Dorsal head scales smooth, or with a low keel.

c. Superciliary ridge less strongly projecting; anterior superciliaries elongate, with oblique sutures.

d. Subdigital lamellae on hind foot not forming a comb.

e. Tail feebly compressed at base, slender and rounded for most of its length.

f. Vertebral crest ends near base of tail, no double crest on tail. Segmental arrangements of caudals (in species with autotomy) not readily apparent.

g. Dorsal body scales polygonal, juxtaposed, smooth or keeled.

h. Males without femoral pores.

i. No gular pouch in males. Throat usually darker but not with an area of intense black.

\section{Enyalioides}

nostril, concave behind, with nostril directed posterolaterally; I or 2 scales between nasal and anterior corner of orbit (Fig. II).

Dorsal head scales compressed, and raised to a high keel, or pyramidal, with several keels.

Superciliary ridge strongly projecting; the anterior superciliary scales not elongate, with vertical sutures.

Subdigital lamellae on hind foot form a distinct comb.

Tail strongly compressed for most of its length.

A double crest most of the length of the tail. Segmental arrangement of caudals very apparent due to marked anterior-posterior increase in scale size within each segment.

Dorsal scales of body variable, homogenous or heterogenous, smooth or keeled, imbricate or juxtaposed, but not as in Enyalius.

Femoral pores present or absent in males and/or females.

Males with a well developed gular pouch, usually associated with a region of intense black on the throat.

\section{Enyalius compared with Anisolepis and Aptycholaemus}

In his description of Anisolepis Boulenger (1885c : 86-7) stated that it is " allied to Enyalius, Urostrophus, and Liosaurus, which have likewise smooth infradigital lamellae, no femoral pores, and, like Polychrus and the Geckonidae, abdominal ribs and no fontanelle in the sternum ". Later, in his description of Aptycholaemus (Boulenger, I89I : 85), he stated that this genus is " allied to Urostrophus, D. \& B., and Anisolepis Blgr., but differs from both in the absence of a gular fold and in dorsal 
lepidosis". Anisolepis and Aptycholaemus are indeed very similar to each other, and of iguanids are most like Enyalius.

Anisolepis, Aptycholaemus, and Enyalius are very similar osteologically, and have in common the following external features: supraorbital semicircles medially separated; juxtaposed, polygonal head scales ; a small but distinct interparietal scale ; a small, convex nasal scale placed laterally below the canthal ridge ; several elongate, overlapping anterior superciliary scales ; dorsal body scales of various sizes and not evenly aligned in rows ; small, juxtaposed lateral body scales ; large ventral scales ; granular postfemoral and posterior suprafemoral scales ; no femoral pores ; a long, slender, rounded tail.

The differences that separate Anisolepis and Aptycholaemus, considering the two together, from Enyalius are few and relatively trivial : they have no vertebral scale row, their distal subdigital lamellae, which are smooth, do not have a median groove, and their hind limbs are shorter, when adpressed reaching no farther than the ear. Aptycholaemus further differs from Enyalius in having no transverse gular fold, and a very small ear opening. Anisolepis further differs from Enyalius in its exceedingly long tail, well over three times the length of the head and body.

Enyalius bilineatus is in some respects transitional between Anisolepis and Aptycholaemus on the one hand, and the remaining species of Enyalius on the other. It is the only form with an elongate subocular scale as in Anisolepis and Aptycholaemus. Although a vertebral scale row is present in $E$. bilineatus it forms at most a low serration rather than a distinct denticulation. The keels of its ventral scales form distinct parallel lines as in Anisolepis and Aptycholaemus. Also, as in these two genera, as well as in some other species of Enyalius, the tail is not autotomic, its subdigital lamellae are smooth, and there is no sexual dichromatism.

\section{REFERENCES}

Boulenger, G. A. I885a. A list of reptiles and batrachians from the province of Rio Grande do Sul, Brazil, sent to the Natural-History Museum by Dr. H. von Ihering. Ann. Mag. nat. Hist., (5) : 15 : 191-196.

I885b. Catalogue of the lizards in the British Museum (Natural History), London, vol. 2, ed. 2, xiii +497 pp., 24 pls.

1885c. Second list of reptiles and batrachians from the Province Rio Grande do Sul, Brazil, sent to the Natural-History Museum by Dr. H. von Ihering. Ann. Mag. nat. Hist., (5) : $16: 85-88$.

I891. Description of a new genus of Iguanoid lizards. Ann. Mag. nat. Hist., (6) : $8: 85$ 86.

Cope, E. D. I876. Report on the reptiles brought by Professor James Orton from the middle and upper Amazon, and western Peru. J. Acad. nat. Sci. Philad., (2) : 8 : I59-183.

Duméril, A. M. C. \& Bibron, G. 1837. Erpétologie générale ou histoire naturelle complète des reptiles, Paris, vol. 4 , ii +57 I pp.

Etheridge, R. 1965. The abdominal skeleton of iguanid lizards. Herpetologica, 21 : I6II68.

Fitzinger, L. 1826. Neue Classification der Reptilien nach ihren natürlichen Verwandtschaften. Vienna, viii +66 pp.

-1843. Systema Reptilium. Fasciculus Primus. Amblyglossae. Vienna, vi + $106 \mathrm{pp}$.

Gans, C. \& Vanzolini, P. E. I953. Status of the South American iguanid lizard, Enyalius coerulescens Cope. Ann. Carneg. Mus., 33 : 125-127. 
Gray, J. E. I831. in Griffith, in Cuvier, The Animal Kingdom, Reptilia. London. 48I pp.

I845. Catalogue of the specimens of lizards in the collections of the British Museum. London. xxviii +289 pp.

Guibé, J. I954. Catalogue des types de lézards du Muséum d'Histoire Naturelle. Paris. II9 pp.

Guichenot, A. I855. in CASTELnaU, Animaux nouveaux ou rares recueillis pendant l'expédition dans les parties centrales de l'Amérique du Sud, de Rio Janeiro à Lima, et de Lima au Para. Reptiles. Paris. 96 pp., I8 pls.

Ihering, H. von. I898. Contributions to the herpetology of Sau Paulo, Brazil. Proc. Acad. nat. Sci. Philad., 49 : 102.

Kaup, J. I826. Monographie der Gattung Uraniscodon. Isis, Jena. 19: 89-91.

I827. Zoologische Monographien. Isis, Jena. 20 : 6ro-625.

LESSON, R. P. I828. in DUPERRY, Observations générales sur reptiles recueillis dans le voyage autour du monde pendant les années I822, I823, I824 et I825. Zoologie (Voyage de la Coquille). 2: I : I-66.

Schinz, H. K. $\quad$ 1835. Naturgeschichte und Abbildungen der Reptilien. Leipzig. 240 pp.

SPIX, J. B. DE. 1825. Animalia Nova sive species novae Lacertarum, quas in itinere per Brasiliam annis MDCCCXVII-MDCCCXX jussu et auspiciis Maximiliani Josephi I. Tomus I, Lacertae. 26 pp., 28 pls.

WAGLER, J. I830. Natürliches System der Amphibien mit vorangehender Classification der Säugthieve und Vögel. München. vi $+35 \mathrm{I}$ pp.

Wettstein, O. I926. Eine neue Eidechse der Gattung Enyalius aus Ecuador. Sber. Akad. Wiss. Wien, 15 : I-2.

Wied-Neuwied, M. I820. Reise nach Brasilien in den Jahren I8I5 bis I8I7. Frankfurt a.M. vol. I, xxxiv $+380 \mathrm{pp}$.

1821. Reise nach Brasilien in den Jahren I8I5 bis I8I7. Frankfurt a. M., vol. 2, xviii + $345 \mathrm{pp}$.

1825. Beiträge zur Naturgeschichte von Brasilien. vol. I, xxii + 614 pp.

Wiegmann, A. F. A. 1834. Herpetologica Mexicana. Seu descriptio amphibiorum novae Hispaniae, quae itineribus comitis de Sack, Ferdinandi Deppe, et. Chr. Guil. Schiede. I. Saurorum species. Berlin. vi +54 pp., Io pls.

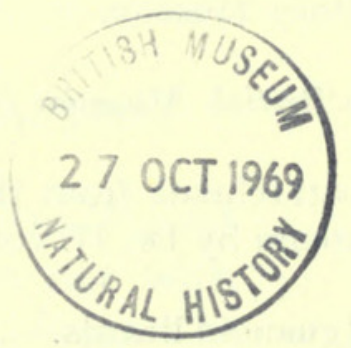

Professor R. Etheridge, Ph.D.

Department of Zoology

San Diego State College

San Diego, Cal.

U.S.A. 


\section{$2 \mathrm{BHL}$ Biodiversity Heritage Library}

Etheridge, Richard. 1969. "A review of the Iguanid lizard genus Enyalius." Bulletin of the British Museum (Natural History) Zoology 18, 233-260. https://doi.org/10.5962/bhl.part.18421.

View This Item Online: https://www.biodiversitylibrary.org/item/20348

DOI: https://doi.org/10.5962/bhl.part.18421

Permalink: https://www.biodiversitylibrary.org/partpdf/18421

\section{Holding Institution}

Natural History Museum Library, London

\section{Sponsored by}

Natural History Museum Library, London

\section{Copyright \& Reuse}

Copyright Status: In copyright. Digitized with the permission of the rights holder.

Rights Holder: The Trustees of the Natural History Museum, London

License: http://creativecommons.org/licenses/by-nc-sa/4.0/

Rights: http://biodiversitylibrary.org/permissions

This document was created from content at the Biodiversity Heritage Library, the world's largest open access digital library for biodiversity literature and archives. Visit BHL at https://www.biodiversitylibrary.org. 